\title{
Relationships between fluvial evolution and karstification related to climatic, tectonic and eustatic forcing in temperate regions
}

Dominique Harmand ${ }^{\mathrm{a}}$, Kathryn Adamson ${ }^{\mathrm{b}}$, Gilles Rixhon ${ }^{\mathrm{c}}$, Stéphane Jaillet ${ }^{\mathrm{d}}$, Benoît Losson ${ }^{\mathrm{a}}$, Alain Devos ${ }^{\mathrm{e}}$, Gabriel Hez ${ }^{\mathrm{d}}$, Marc Calvet ${ }^{\mathrm{f}}$, Philippe Audra ${ }^{\mathrm{g}}$

a'Laboratoire LOTERR, Université de Lorraine, site Libération, BP 13387, 54015 Nancy, (F). dominique.harmand@univ-lorraine.fr, benoit.losson@univ-lorraine.fr

${ }^{\mathrm{b}}$ School of Science and The Environment, Manchester Metropolitan University, M1 5GD Manchester(UK). k.adamson@mmu.ac.uk

cUniversity of Cologne Institute for Geography, Albertus-Magnus-Platz 50923 Köln (D). grixhon@uni-koeln.de

${ }^{\mathrm{d}}$ Laboratoire EDYTEM, Université de Savoie, CNRS, Pôle Montagne, F - 73376 Le Bourget du Lac (F).Stephane.Jaillet@univ-savoie.fr, gabrielhez@orange.fr

eGenenaa, 2 esplanade Roland Garros 51100 REIMS (F). alain.devos@univ-reims.fr fUniversité de Perpignan-Via Domitia, UMR 7194 HNHP, 66860 Perpignan Cedex (F). calvet@univ-perp.fr

'Polytech Nice - Sophia Université de Nice - Sophia Antipolis 930 route des Colles 06903 Sophia-Antipolis (F). audra@unice.fr

\section{Abstract}

This paper reviews the diversity of relationships between river evolution and karstogenesis. It also underlines the fundamental role of numerical dating methods (e.g. cosmogenic nuclides) applied to sedimentary sequences in tiered cave passages as they have provided new insights into these complex interactions. Although karst terrain is widespread worldwide, we focus on European karst catchments, where the sedimentary records are especially well preserved. We review the recent dating of fluvial sediments and speleothems, to examine the timing of karstification, incision and deposition in cave levels. The most complete alluvial records occur in tectonically uplifted high mountains where some of the oldest sediment fills date to the Miocene. Evidence indicates that not only uplift, but also climatic conditions and fluvial dynamics (e.g. knickpoint retreat, increased channel flow and/or sediment load, and stream piracies) can play a major role in speleogenesis and geomorphological evolution. In evaporite rocks, speleogenesis is characterized by rapid dissolution and subsidence. In European catchments, gypsum cave development largely occurred during cold climate periods, while 
limestone caves formed during warm interglacial or interstadial phases. Our synthesis is used to propose four models of fluvial and karst evolution, and highlight perspectives for further research.

Keys words: karst, speleogenesis, valley incision, aggradation, base level, cave level, phreatic cave, cosmogenic nuclide dating

\section{Introduction: links between karst and fluvial systems}

\subsection{Conditions and processes of karstification}

Karst terrain is characterised by underground drainage networks and (sub)surface features such as dolines, poljes, sinkholes, and caves (Palmer, 2007). It is typical of regions of limestone, evaporite and marble bedrock, but also develops in siliceous (sandstones and quartzites) and other metamorphic rocks (Ford \& Williams, 1989; Bigot \& Audra, 2010). According to Ford and Williams (1989), karst is globally present in all climate domains, but the widest areas of karstified terrain are in the limestone and evaporite regions of Europe and Asia (Figure 1). Karstification is the process of water infiltration and dissolution, mainly through chemical mechanisms, involving the presence of water and carbonic acid. This definition implies strong links between karst and fluvial activity, especially for epigenetic speleogenesis which involves the vertical organization of 'three karstic horizons' (Mangin, 1975; Audra \& Palmer, 2013): the infiltration of water at the surface; the flow of water through karstified limestones or evaporites; and the emergence of water from karst conduits at the valley bottom (Ek, 1961; Delannoy, 1997; Audra, 2010, Figure 2A, 2B). Water flow, and resulting sediment transport, along the three 'karstic horizons' (Mangin, 1975) means that subaerial fluvial forms such as terraces, often contain only generalized records of palaeo-base and cave levels. Therefore, the core topic of this contribution focuses on the combined analysis of surface alluvial sequences and subterranean (endokarst) geomorphology and sediment fills, which produces more complete reconstructions of palaeofluvial activity in karst settings.

In karst regions, alluvium is often well-preserved in endokarstic cavities. The most distinctive endokarstic features are the horizontal tubes that form in the saturated zone: syngenetic and paragenetic galleries, the latter of which form upward to the water table (e.g. Ford \& Williams, 1989; Quinif, 1989). These features correspond to periods of base level stability in the fluvial system. In contrast, meandering canyons and vadose shafts form in the unsaturated zone, and 
may be correlated to incision in the adjacent valleys (Audra \& Palmer, 2011). The transition from phreatic to vadose conditions produces keyhole (T-form) features, and the reshaping of previously enlarged passages and narrow and deep underground canyons during river entrenchment phases.

In limestone karst, cave formation occurs due to the dissolution of bedrock by unsaturated water containing carbonic acid (from $\mathrm{CO}_{2}$ ) (Palmer, 1991). The maximal denudation rates in the temperate zone occur in the wetter oceanic regions (even in wet subarctic areas), such as in Chilean Patagonia (100 mm/ka, Hobléa et al., 2001) or in the Vercors, French subalpine chains (120-170 mm/ka, Delannoy, 1982), and primarily depend on the amount of precipitation (Palmer, 1991). Under interglacial and interstadial conditions, forest soils are well-developed, and these can be an especially aggressive dissolution agent (Ford \& Williams, 1989; Quinif, 2006). White (1988) highlighted the existence of thresholds in the development of cave passages. First, a laminar flow regime produces micro-caves (diameter: 5-10 $\mathrm{mm}$ ) during an initiation phase of 3-5 $\mathrm{ka}$. Then, turbulent flow can shape 1-3 m conduits within a few thousand years during a phase of enlargement. In high alpine mountains, where high precipitation and acidic forest soils mean that cave development can be especially rapid, wide conduits (from 1 to $10 \mathrm{~m}$ ) can appear in a few hundred years (Ford \& Williams, 1989).

The propagation of groundwater through a karst system is largely determined by its structural framework (Ford \& Williams, 1989). In limestone, only planes of penetrable fissures (e.g. bedding planes, stratification joints, faults) have sufficient permeability. In rocks with greater fracturation, permeability is higher due to decreased anisotropy (Bazalgette \& Petit, 2005). For example, in folded rocks that have been subjected to tectonic stresses, fissure frequency and therefore permeability, is generally higher (Ford \& Williams, 1989). Fissure frequency also increases over time, in relation to solvent water infiltration (Gabrovšek et al., 2014) and rock decompression due to valley entrenchment. These structural controls on subterranean morphology also explain the existence of caves in non karstified areas: opened faults, underground collapse structures, or caves shaped in impervious rocks. For example, the Verna cave (Pyrenees, the biggest cave chamber in France), is mainly situated in Carboniferous sandstone and shales (Gilli, 2010). In general, geomorphological maps of karstified areas show parallel horizontal passages, aligned with the main regional fractures (Losson, 2003) and, sometimes, a gridded cave network of intersecting, fracture-controlled fissures (Palmer, 1991; Audra \& Palmer, 2011). However, fluvial geometry can develop independently of structural 
controls, such as in the Eastern Paris Basin, where rivers are superimposed on the Mesozoic strata (Le Roux \& Harmand, 1998, 2003).

\subsection{Types of cave sedimentary fill}

Cave deposits are highly variable in their origin and characteristics, and include allochthonous and autochthonous sediments which can be broadly categorized as coarse and fine-grained clastic sediments, and carbonate precipitates. The most common cave formations are the coarse clastic deposits of the entrance facies. In the glaciated parts of Europe and North America much of this clastic material is derived from glacial till and deglacial sediments (Granger et al., 2001). In non-glaciated areas, clastic deposits are the result of bedrock breakdown and decompression close to the valley sides as well as cryoclastic processes at the cave entrance (Campy, 1982). Cryoclastic sediments can include palaeontological and/or archaeological remains, such as in the "Belle-Roche" cave, developed in the Carboniferous limestone of the Amblève valley (Ardenne massif, E. Belgium; Cordy et al., 1993; Rixhon et al., 2014). There, the archaeopalaeotolongical layers overlie basal Amblève gravels, indicative of a palaeovalley floor position (Rixhon \& Demoulin, 2010). The presence of such coarse sediments, deposited by high energy flows, generally indicate a period of enhanced fluvial activity in the cave environment (Ford \& Williams, 1989).

Secondary carbonates are formed by the dissolution of calcium carbonate in the karst bedrock and its reprecipitation, producing features such as tufa, travertine, and speleothems (Couchoud, 2008). These precipitates develop in association with prevailing environmental conditions, and reflect changes in water percolation, evaporation and degassing. They can therefore provide valuable records of palaeoclimate, palaeoecology, and palaeogeomorphology - since tufa and travertine cap palaeoland surfaces. Moreover, they can be dated by radiocarbon $\left({ }^{14} \mathrm{C}\right)$ and Uranium-series (U-series) methods. Speleothems in particular can provide very high temporal resolution palaeoclimatic data due to their banded nature. Tufa and travertine (sensu lato) are more complex, and can form in multiple, superimposed horizons or tiered steps of different ages (Ford \& Williams, 1989).

\subsection{Markers of Pleistocene valleys evolution}


136 Many studies have thoroughly discussed the relationships between karst terrain and catchment 137 sediment flux, incision and aggradation (Benito et al., 1998, 2010; Granger \& Palmer, 2001; 138 Jaillet et al., 2004; Mocochain et al., 2009; Audra \& Palmer, 2011; Guifang et al., 2011; Calvet 139 et al., 2015; Columbu et al., 2015). During the Pleistocene, karst evolution was conditioned by 140 climatically-driven cycles of river incision and aggradation, operating over $41 \mathrm{ka}$ and $100 \mathrm{ka}$ 141 timescales (Bridgland \& Westaway, 2007). In most cases, cave levels formed following 142 entrenchment of rivers into limestone rocks, lowering the piezometric level. Incision into 143 preexisting alluvium and the substratum occurred either during warm-cold (e.g. karst of $\mathrm{N}$ 144 France; Antoine, 1994) or cold-warm transitional periods (e.g. British karst; Bridgland \& 145 Westaway, 2007; Lewin \& Gibbard, 2010). Aggradation occurred chiefly during cold periods, 146 characterised by massive deposition of gravel and sand,. Evidence of other cold climate 147 indicators, such as ice-rafted blocks, ice wedges, and cryoturbation, have also been identified 148 in karst alluvial sequences. River gravels at the valley bottom (e.g. Antoine et al., 2006) or 149 terraces (e.g. Bridgland et al., 2009) are sometimes covered by interglacial or interstadial 150 alluvial silt, soils, peat, and tufa.

152 Evidence of progressive stacking of alluvial sequences indicates the raising of cave level (Audra 153 \& Palmer, 2011), while fill-in-fill terraces imply a succession of lowering and raising of base 154 and caves levels. At the valley scale, Pleistocene uplift generates tiered terraces provided that 155 progressive vertical fluvial incision was accompanied by lateral erosion due to channel 156 migration (Lewin \& Gibbard, 2010). In karst areas where only few remnants of strath terraces 157 are preserved along deeply-incised canyons, only infilled caves can be used to precisely reconstruct the evolution of Pleistocene valley entrenchment (Audra et al., 2001).

159 In karstic fluvial settings, sediment sources, transportation and deposition characteristics vary 160 in accordance with Quaternary environmental changes. On the one hand during glacial and 161 periglacial periods, enhanced sediment mobilization means that clastic sediment can become 162 trapped in caves and karst depressions (Audra et al., 2001; Audra, Ed, 2010; Rixhon et al., 163 2014; Calvet et al., 2015). In areas covered by ice-sheets, sedimentation ceases. On the other 164 hand, during interstadial, interglacial, and postglacial climates, tufa, travertine, and speleothems generally developed as a result of prolonged valley floor stability (Delannoy, 1997; Frank et al., 2006; Limondin-Lozouet et al., 2006; Couchoud, 2008).

168 Endokarstic alluvial deposits thus have the potential to offer a valuable record of Quaternary river system evolution. However, fragmentary nature of endokarstic deposits, and their 
integration with other sedimentary records over different timescales are two key issues that need to be addressed. Can endokarstic fluvial deposits be reliably integrated with other alluvial records to produce a model of Quaternary valley evolution? Can we combine records from fragmentary time slices into the same landscape evolution model (valley terraces, isolated endokarstic remnants, tiered passages in karst massifs)?

This paper presents a synthesis of recent research in European karst river systems (where appropriate, we also refer to well-studied non-European karst settings), developed within the modern temperate climate zone (Fig.1). It considers multiple spatial scales, from localized cave deposits to regional palaeoenvironmental reconstructions. It also discusses climatic, glacial, tectonic, isostatic, and eustatic forcing on karstogenesis (lowered sea level causes rejuvenation of karst processes, and subsequent raised sea level generates successive cave levels in systems fluvially linked to coastal locations), as well as the increasing application of dating methods on alluvial sediments in karst terrains, such as U-series, terrestrial cosmogenic nuclide (TCN) and ${ }^{14} \mathrm{C}$. We establish a typology of the relationships between speleogenesis and fluvial incision/aggradation. Finally, we propose four conceptual models of karstic fluvial development based on the reviewed literature.

We examine their Quaternary development which is influenced by periglacial and glacial processes in mountain settings. In glaciated areas, fluvial discharge would have been directly linked to glacier mass balance (see 4.3). In periglacial settings, river flow regime would have been strongly influenced by precipitation and temperature variability.

\section{Dating methods in karstic environments}

Until the 1980s and 1990s, relative dating techniques (notably palynology and palaeomagnetism) were the primary methods used to estimate the age of fluvial deposits in karst terrain (Ford \& Williams, 1989). Several numerical dating methods, such as thermoluminescence (TL, Huxtable and Aitken, 1991), uncalibrated radiocarbon $\left({ }^{14} \mathrm{C}\right.$, Bastin \& Gewelt, 1986) and Uranium-series (U-series) in caves and river terrace calcrete were also used (Ambert \& Ambert, 1995). Advances in numerical dating methods during the last two decades have allowed more robust chronologies to be developed (Couchoud, 2008; Richard et al., 2015; Rixhon et al., 2016). Calibrated radiocarbon ages (cal $\left.{ }^{14} \mathrm{C}\right)$, optically stimulated luminescence (OSL, e. g. Vernet et al., 2008), and electron spin resonance (ESR, e. g. Moreno 
et al., 2012) techniques have become more widely applied. Terrestrial cosmogenic nuclide

205 (TCN) dating of karst environments, especially burial dating, has also greatly enhanced the understanding of complex interactions between karst and fluvial systems (Granger et al., 1997).

\subsection{Numerical methods to date tufa, travertine and fluvial calcrete}

Secondary carbonates, such as tufa, travertine, calcrete and speleothem, have been widely used to date landscape change in karst environments, most commonly using U-series methods $\left({ }^{230} \mathrm{Th} / \mathrm{U},{ }^{231} \mathrm{~Pa} /{ }^{238} \mathrm{U},{ }^{234} \mathrm{U} /{ }^{238} \mathrm{U},{ }^{206} \mathrm{~Pb} /{ }^{238} \mathrm{U}\right)$. At Pierre-la-Treiche, located along the entrenched Mosel valley into the Bajocian limestones (NE France), U-series ages of speleothems in fossil caves indicated that their growth was correlated to marine isotope stage (MIS) 6.5, 5.3, 3.3, 3.1, and 1 (Losson et al., 2006). The U-series ages were used to identify several abrupt warming phases during MIS 3 - a cold period recorded in the Greenland ice cores and in the Grande Pile peat record from the Southern Vosges mountains, NE France (Pons-Branchu et al., 2010). Useries analysis of pedogenic and groundwater calcrete horizons has also been used to constrain the timing of fluvial aggradation in karst settings such as the Sorbas basin of SE Spain (Candy et al., 2015) and the limestone Orjen massif, western Montenegro (Adamson et al., 2014), respectively.

A chronology based on multiple dating methods allows us to rigorously examine the relationships between fluvial evolution and karstification, where tiered travertine steps increase coherently with terrace age, or if there is a more complex terracing history involving cut-andfil terraces, for example. A good example is the Tarn valley, near Millau (S France), where the dating framework has been a matter of debate (Ambert \& Ambert, 1995). Based on the presumed ages of the travertine steps, the rate of incision of the Tarn Canyon was thought to be very low. However, recent OSL dating as well as palaeoecological and palaeontological analyses showed that the majority of travertine steps (Peyre) formed during MIS 5e-5b (Vernet et al., 2008). This indicates that the incision rate in the Tarn valley has reached $>30 \mathrm{~cm} / \mathrm{ka}$ since the deposition of the $\sim 75$ ka-old terrace 3 (MIS 5b-5a), located $25 \mathrm{~m}$ above the valley floor. Secondary carbonate-based chronologies can be used alongside stable oxygen $\left(\delta^{18} \mathrm{O}\right)$ and carbon $\left(\delta^{13} \mathrm{C}\right)$ isotope ratio analysis to provide a record of interglacial climatic changes (Dabkowski et al., 2011, 2016), such as interglacial tufas in France (e.g. La-Celle-sur-Seine, 


\section{2. ${ }^{26} \mathrm{Al} /{ }^{10} \mathrm{Be}$ burial dating of cave-deposited alluvium}

241 Burial dating is based on the differential decay of at least two cosmogenic nuclides (Granger and Muzikar, 2001). Amongst them, the pair ${ }^{26} \mathrm{Al} /{ }^{10} \mathrm{Be}$ is very well suited because: 1) both nuclides are produced in quartz, 2) their production ratio is fundamentally independent of latitude and altitude, and 3) it varies only slightly with depth (Dunai, 2010). Burial dating is useful in those settings where previously exposed quartz-bearing material (i.e. for ${ }^{26} \mathrm{Al} /{ }^{10} \mathrm{Be}$ ) becomes shielded from cosmic rays. Two basic assumptions must be fulfilled for a fast and complete burial (Granger and Muzikar, 2001). First, the time span over which incomplete shielding occurs is much shorter than the subsequent burial duration. Second, shielded sediments are buried deeply enough, i.e. in practice $\geq 30 \mathrm{~m}$ (rock equivalent mass), implying an insignificant production through muons at depth. We refer to the comprehensive works of Granger and Muzikar (2001), Dunai (2010) and Granger (2014) for further information about the basic principles of burial dating, including mathematical developments.

In the fluvio-karstic context, the burial event is achieved when river sediments, formerly exposed to cosmic rays at the Earth surface during hillslope denudation and fluvial transport, are washed into an underground system. The two aforementioned prerequisites are frequently met for in-cave deposited alluvium; the study of Granger et al. (2001) in Mammoth cave (i.e. the longest cave system known in the world, developed in Mississipian limestones in the Kentucky Appalachian Plateau) is one of the first successful applications of burial dating to such sediments. Since then, quartz-bearing material deposited into different multi-level cave systems by streams or rivers flowing into the sub-surface has been dated in a range of tectonically-active (e.g. Stock et al., 2004) or moderately-uplifted (e.g. Anthony and Granger, 2007) settings. Inferring long-term river incision rates in these environments relies on the key assumption that the alluvium deposited in a horizontal, hydrologically abandoned, phreatic tube represents the last time the passage was at the local water table (Anthony and Granger, 2007). The selection of suitable sampling sites should ensure that abandoned and alluvium-filled phreatic tubes were not contaminated by any reworked material from an older (or younger) depositional episode (Dunai, 2010). It is therefore recommended to sample sediment layers displaying fluvial features or structures (Anthony and Granger, 2007) and/or where other material allows a cross-check with an independent dating method (e.g. U-series dating of a speleothem/flowstone sealing the fluvial sequence; Stock et al., 2005). 
273 In Europe, this approach, sometimes used in combination with paleomagnetism and U-series 274 dating, was mostly applied to cave systems of mountainous environments: both in the Eastern 275 (Wagner et al., 2010; Häuselmann et al., 2015) and the Western Alps (Häuselmann et al., 2007; 276 Hobléa et al., 2011), and in the Pyrenees (Calvet et al., 2015). Three case studies exemplify the 277 value of burial dating of in-cave deposited alluvium to unravel long-term landscape evolution 278 in diverse karstic environments (Fig. 2). First, the Têt valley (Eastern Pyrennées, France) shows 279 nine karst levels, between 1400 to $400 \mathrm{~m}$ a.s.l., along its epigenetic fluvial gorge cut into the 280 Devonian limestones of Villefranche de Conflent, with caves filled by sand and siliceous pebbles (Calvet et al., 2015). Level 5 was dated from the lower Pliocene and level 3 from the Early Pleistocene, allowing an estimate of an incision rate of $\sim 52 \mathrm{~m} / \mathrm{Ma}$, with a clear acceleration to $90 \mathrm{~m} / \mathrm{Ma}$ for the last Ma. Level 3 is clearly linked to the upper terrace of the Têt valley and all the lower cave levels and sublevels strongly correlate to the younger terrace levels. Second, burial ages from different speleogenetic levels of the Siebenhengste-Hohgant cave system (Aare catchment, Switzerland) revealed a remarkable increase of glacial valley lowering since the beginning of the Middle Pleistocene, which substantially postdates the onset of glaciation in this region (Häuselmann et al., 2007). This might be related to a considerable lowering of the equilibrium line altitude and the transgression of threshold conditions beyond which increase in glacial downcutting rates becomes nonlinear (Brocklehurst and Whipple, 2004). Third, burial ages coupled with magnetostratigraphy in multi-level cave systems along the Ardèche valley indicated a stepwise karst genesis during the Plio-Pleistocene, consistent with the per ascensum model of Mocochain et al. (2009), after the Messinian salinity crisis (Tassy et al., 2013) especially, during the rise of sea level in the Lower Pliocene. These data also highlighted an uplift rate of $\sim 30 \mathrm{~mm} / \mathrm{ka}$ since $1.8 \mathrm{Ma}$ in the lower Ardèche area.

\subsection{Strengths and weaknesses of dating methods}

Each numerical dating technique has an upper age limit (e.g. U-series: c. 350 ka; OSL: c. 150$200 \mathrm{ka} ;{ }^{26} \mathrm{Al} /{ }^{10} \mathrm{Be}$ burial dating: c. $5.5 \mathrm{Ma}$ ) and associated analytical uncertainties. Ages obtained from adjacent karstic areas, or even within the same valley, can vary considerably. For example, in the Sierra of Atapuerca and the Arlanzón Valley (Moreno et al., 2012) and in the upper Mosel catchment (Harmand \& Cordier, 2012), TL, IRSL, ESR and U-series ages provided divergent results. In such instances, different ages may reliably represent spatial variations in uplift rates, river incision and karstification. However, it must be borne in mind 
that these dating methods provide age information about different processes of landscape evolution. Whereas burial ages give constraints about the last time the phreatic passage was at the local water table, U-series ages date the timing of calcite formation and thereby provide minimum ages of sediment deposition. A clear understanding of the chronostratigraphic framework is therefore essential. Detailed geochronological studies, using multiple dating methods, are required to reliably quantify rates of incision and karstification.

\section{Approaches for examining drainage evolution in karstic terrains}

The relationship between valley incision and karstification are summarized in Figure 3. Much research has focused on the impacts of valley entrenchment on karst development, which can in turn provide important insights into fluvial evolution. However, karst development can occur independently of valley evolution, especially when dealing with the ghost-rock process (i.e. rock transformation by self-volume chemical dissolution; Vergari \& Quinif, 1997) or hypogene karstification (i.e. dissolution and crystallization along ascending, often hydrothermal, flows; Hill, 1987). A number of studies have highlighted the influence of karst terrain on valley incision (Figure 3).

Analysis of the relationship between fluvial evolution and karstification requires a multiscale approach, evolving from the valley bottom to the karst, and from the karst to the valley. This review proposes a typology of relationships between karst and valley, depending on morphostructural framework, lithology, base level change, and climatic fluctuations (emphasizing the role of glaciers).

3.1. From the valley bottom to the karst: relationships between karst cave level and valley

\section{base level}

Many studies have highlighted the relationships between base level or cave level and the

334 regional evolution of river systems controlled by climatic, tectonic and/or eustatic forcing 335 (Ambert \& Ambert, 1995; Jaillet, 2000; Audra et al., 2001; Losson, 2003; Harmand et al., 2004; 336 Wang et al., 2004; Mocochain et al., 2009; Guifang et al., 2011; Ortega et al., 2013; Tassy et al., 2013). As a result, it is well-established that karstic levels can provide valuable altitudinal markers, or 'dip sticks' for river incision. This is especially effective in mountain massifs where 
local relief can exceed several kilometers, and multiple cave levels exist, therefore providing

340 long-term records of fluvial evolution since the Plio-Pleistocene.

342 Karst plays a major role in the formation and preservation of the fluvial sedimentary record.

343 Where alluvial sediments accumulated in karst depressions, they became more immune to 344 subsequent erosion and reworking (Delannoy, 1997; Audra et al., 2001). Ancient alluvium is 345 reported to have been preserved within karst settings since the Early Pleistocene (Wagner et al., 346 2010; Adamson et al., 2014; 2016); the Neogene (Hobléa et al., 2011; Calvet et al., 2015), the 347 Paleogene (Bruxelles et al., 2013) and even the Mesozoic (Vergari \& Quinif, 1997), Palaeozoic 348 (Osborne, 2007) and Precambrian (Buffard \& Fischer, 1993). The excellent preservation 349 potential of these records means that they are valuable archives of landscape change. This is 350 especially the case where palaeovalleys or alluvial terraces are not well-preserved at the surface, 351 when karstic cavities are disconnected from adjacent valleys, due to headward erosion 352 (Enjalbert, 1967, in Nicod, 2010); or when there have been changes to drainage patterns 353 (Adamson et al., 2014). However, correlations between cave deposits and valley fills at the 354 surface are sometimes difficult when karstic sediments are present only in isolated fragments, 355 due to erosion and reworking of the exposed sediments (Quinif \& Maire, 1998).

\subsection{From the karst to the valley: Base level controls on the geometrical organization of} karst drainage networks

Assuming that initial cave development occurs along the water table, Ford and Ewers (1978) proposed a conceptual framework called the "four-state model". In this model, different types of caves evolve depending on increasing fissure frequency through time: 1) bathyphreatic caves, with a few deep phreatic loops (Figure 2B.a, c, d); 2) phreatic caves with multiple and shallower loops (Audra \& Palmer, 2011); 3) caves with a mixture of phreatic and water tablelevelled components; and 4) an idealised water table cave without loops, formed as a result of high fissure frequency. The four-state model has been reinterpreted by Häuselmann (2002), Audra \& Palmer (2011) and Gabrovšek et al. (2014) who pointed out two main controls in relation to valley incision: 1) The recharge control occurs in dammed aquifers, when recharge is fairly regular. Thus, the main endokarstic drain is established at the water table at the same altitude as the valley bottom (Figure 2B.b). When an irregular recharge occurs, looping tubes develop throughout the epiphreatic zone (Figure 2B.a). 2) The base-level control corresponds to the development of perched cave levels. Base level lowering is common in most temperate 
climate karstic areas, especially mountainous regions, due to uplift of the continental crust and associated river incision (Figure 2A, Fig. 2B.c). In contrast, base-level rise produces flooded cave levels and Vauclusian springs, when water ascends (Figure 2B.c). Deep-phreatic cave systems, for instance, are located around the Mediterranean Sea, as a result of the Messinian marine regression and near instantaneous Pliocene flooding (Mocochain et al., 2009).

\subsection{A multi-scale approach}

To effectively capture the complexity of karst evolution, and securely identify the relationships between fluvial activity and karstification, multi-scale analysis should be used to combine large-scale studies of karstified massifs and entrenched valleys, and local-scale analysis of individual karst drains and sediment fills. In valleys entrenched up to several hundred meters deep, numerous studies (Webb et al., 1992; Audra et al., 2001; Losson et al., 2006; Guifang et al., 2011; Rixhon et al., 2014) have highlighted the altitudinal relationship between karstic passages and stepped terraces (Figure 2A). At the valley scale, establishing the elevation of alluvial terraces and karstic drains to within a few metres is sufficient for reliable geomorphological reconstructions. For example, in the Sierra de Atapuerca and the Arlanzón valley (Iberian Chain, Eastern Burgos, Spain), geomorphological analysis was combined with archaeology, palaeomagnetics, TL, IRSL, U-series and ESR dating to develop a chronostratigraphical framework of fluvial incision and speleogenesis of karst caves during the Lower and Middle Pleistocene (Moreno et al., 2012; Ortega et al., 2013).

At even larger spatial scales, across the Mediterranean basin for example, karstic and palaeovalley features suggest a common regional pattern of geomorphological evolution. At the Mediterranean coast, such as the South-East of France, Messinian canyons and Pliocene rias, among other features, demonstrate that sea level change has had a major influence on karstification (Audra et al., 2004). Late Miocene base-level fall was followed by rising baselevel in the Pliocene, which flooded lower endokarstic levels, and karst waters discharged as Vauclusian springs. In this system, higher elevation karst horizons are more recent forms, as indicated by per ascensum speleogenesis.

At smaller spatial scales, in individual caves or valleys, high-resolution analysis is essential when caves are disconnected from neighbouring valleys - due to erosion of the limestone valley sides or of terrace remains. For example, in the Pierre-Saint-Martin cave, Pleistocene deposits 
of the Aranzadi gallery recorded a succession of depositional and entrenchment phases (Quinif $\&$ Maire, 1998). Three groups of speleothems situated between the detrital units highlighted the succession of several interglacial or interstadial stages allowing the precipitation of carbonate. U-series dating showed that speleothem growth occurred during MIS 9, 7 and earlyMIS 6. In the Têt river basin, recent research has provided precise correlations between aggradation and incision phases in each glacial cycle (Hez et al., 2015; see section 5 for discussion).

\section{A typology of the relationship between fluvial evolution and karstification}

As outlined above, fluvial incision and karstification in limestones or evaporite rocks are driven by a number of factors. The most central are: eustasy, isostasy, climate and tectonics. Here we discuss the relationships between valley evolution and speleogenesis using examples from across Europe, as well as key studies in Australia, North America, and the Tibetan Plateau. Four models of valley evolution and karstification are proposed.

\subsection{Karstification in association with base and cave level lowering}

A number of karst systems have horizontal tubes and vertical conduits which reflect stability and incision in the neighbouring valleys, respectively. These valleys often contain stepped alluvial terraces associated with aggradation/incision cycles. Generally, epigenetic speleogenesis of limestone massifs and the succession of valley incision and aggradation are largely associated with strong isostatic or tectonic uplift. Climatic forcings have also played a key role, especially at the onset of the Quaternary, and during the Mid-Pleistocene Revolution at the onset of the $100 \mathrm{ka}$ Milankovitch cycles (Bridgland et al., 2009). Four types of geomorphological evolution are distinguished in the following discussion, based on the relief energy/topography of the karstified region.

\subsubsection{Karstification in low elevation and very stable cratonic area}

The Devonian limestone region of Buchan (South-East Australia) is a valuable example of slow, long-term incision and speleogenesis. Three fluvial terraces and epiphreatic cave levels have developed below a height of $30 \mathrm{~m}$ above the adjacent river (Webb et al., 1992). Geomorphological evidence and palaeomagnetic dating indicate that these formed before 780 $\mathrm{ka}$, giving a maximum incision rate of $38.5 \mathrm{~mm} / \mathrm{ka}$. The Buchan area has experienced only 4-5 
$\mathrm{m}$ incision over the last $40 \mathrm{Ma}$ (i.e. $0.1-0.125 \mathrm{~mm} / \mathrm{ka}$ ), 2-3 $\mathrm{m}$ of this has occurred over the last $730 \mathrm{ka}($ i.e. $2.7-4.1 \mathrm{~mm} / \mathrm{ka})$.

\subsubsection{Karstification on low altitude plateaus (<500 $\mathrm{m}$ a.s.l.)}

\subsubsection{General cases}

There are many examples of epigenetic speleogenesis and fluvial incision as a result of moderate (up to $10 \mathrm{~mm} / \mathrm{ka}$ ) uplift in cratonic areas, sedimentary basins, and low-altitude $(<500$ m-a.s.1.) basement plateaus, such as in the Paris, Aquitaine basins (Bridgland et al., 2009; see in Audra, Ed., 2010) or British karst (Waltham et al., 1997). In North America, the karst evolution of the Kentucky Appalachian Plateau has been dated in detail using TCN ages (Granger et al., 2001). These karstic areas broadly correspond to one of two morphostructural settings. 1) Extended horizontal or monoclinal strata of Palaeozoic age (e.g. the Kentucky Plateau, USA: Granger et al., 2001), Mesozoic or Cenozoic karstified rocks (e.g. in the plateaus of the Eastern Paris Basin, France; Jaillet, 2000; Losson, 2003; Devos et al., 2007). 2) Folded strata in Alpine or older (e.g. Appalachian) structures. In most cases the caves are located in narrow outcrops of limestone, such as the Devonian and Carboniferous rocks of the Ardenne massif, Belgium (Quinif, 1999, 2006).

There have been several studies of Pleistocene sedimentary sequences from caves and river terraces formed on low-level plateaus (Losson, 2003; Jaillet et al., 2004). These studies show that Pleistocene incision rates were low, and reached up to $100 \mathrm{~mm} / \mathrm{ka}$ in the Mosel catchment (Harmand and Cordier, 2012). On low-elevation karst plateau, there is evidence for Quaternary rejuvenation of older palaeo-karsts or crypto-karsts, such as the Belgian Ardenne, Eastern Paris Basin, and Quercy plateaus (Bruxelles et al., 2013; Vergari and Quinif, 1997; Harmand et al., 2004). At Poissons (Eastern Paris Basin, France), Pleistocene incision of the upper Marne reached $42 \mathrm{~mm} / \mathrm{ka}$ to $58 \mathrm{~mm} / \mathrm{ka}$, and extended below the base of the palaeokarstic wells, which were filled with continental Infra-Cretaceous (Wealdian) ferruginous deposits (Harmand et al., 2004). However, the presence of Late Pleistocene fauna and MIS 6 speleothems in the sediment fill (Jaillet, 2000) was indicative of a Quaternary karstification of the older palaeo-karsts.

\subsubsection{The relations between rivers, aquifers and karst in the Eastern Paris basin}


In the Eastern Paris Basin, epigenetic speleogenesis and fluvial incision is linked to the structural framework of the basin and entrenchment of the main valley into the alternating marl and limestone strata (Losson, 2003; Devos et al., 2009, 2015). The main feature is the position of the river with regard to the water table. Four situations can be distinguished (Figure 4A). 1) When perched rivers are entrenched into limestone above the saturated zone, infiltration occurs into and under the valley from local or allochtonous flows (Jaillet, 2000; Losson, 2003; Devos et al., 2009, 2015; Figure 4A level a). 2) When the surface river channel is in contact with the water table of the saturated zone, the lack of hydraulic gradient induces a ghost rock process around the fractures of the valley floor (Quinif, 2010, Devos et al., 2011; Figure.4A level b). In contrast, lowering of the piezometric level, due to fluvial incision, causes the discharge of residual deposits of the ghost rocks and the creation of conduits in the epiphreatic zone. 3) When the surface river channel is strongly entrenched into the limestone substratum, and drains the flooded karst zone, a thin piezometric horizon develops (Figure 4A level c). 4) If fluvial incision occurs in the marls or clays situated below the saturated zone, the perched karstified zone is disconnected from the river (Figure 4A level d) and the flooded zone drains into low flow springs (Devos et al., 2015). However, as shown in Figure 4B, it is important to remember that the faulted tectonic basement can produce structural and aquifer compartments which control the hydraulic gradient between aquifers and rivers (Devos et al., 2007). This can have major impacts on the hydrological and geomorphological connectivity, between karst and subaerial fluvial drainage networks.

\subsubsection{Relationships between fluvial incision/aggradation and karstification on high altitude plateaus and low mountain ranges $(500-2,000$ a.s.l.)}

In low mountain ranges and high plateaus, a moderate uplift rate (up to 100-200 mm/ka) commonly causes deep fluvial incision and epigenetic speleogenesis in thick limestone strata. On some high plateaus, geomorphological processes have continuously shaped the landscape since the Neogene. In the Southern part of the Causse of Larzac, four stages of speleogenesis were identified from the Middle Miocene until the Pliocene (Camus, 1997, 2010). Even during the Pleistocene, there is evidence of phases of incision and karstification in many regions, such as the Sierra de Atapuerca and the Arlanzón valley (Moreno et al., 2012; Ortega et al., 2013), the Languedocian plateaus (Audra et al., 2001) or the Swabian Alb (Abel et al., 2002). These speleogenetic phases occurred in response to base-level and cave-level lowering, due to tectonic uplift and glacially-driven sea level change. During Pleistocene glacial stages, sea level fell by 
up to $140 \mathrm{~m}$ below modern levels (Rohling et al., 2009). In some settings, such as the_Arlanzón and Ardèche valleys, incision has reached over $100 \mathrm{~m}$ deep since the Lower Pleistocene. The number of terrace levels varies between the narrow middle Ardèche valley (4) and the wide Arlanzón valley (14), but the karstified massifs exhibit only 2 or 3 cave levels, respectively (Audra et al., 2001; Moreno et al., 2012; Ortega et al., 2013).

\subsubsection{Long-term records of fluvial incision and karstification in high mountain regions} $(>2,000$ m a.s.l.)

Many high altitude limestone mountains contain horizontal cave networks at elevations exceeding 2,000 m a.s.1. (Feichtnerschacht, Austrian Alps: 2,000 m; French subalpine chains: 2,300 m; Dolomites, northeastern Italy: 2,775 m; Siebenhengste-Hohgant-Höhle, Berner Oberland, Switzerland >2,000 m; Häuselmann and Granger, 2005; Audra et al., 2007; Wagner et al., 2010, Hoblea et al., 2011; Figure 5A). Many of these mountains contain thick horizons of karstified rock that extend vertically for up to $1 \mathrm{~km}$, and are characterized by cave to rock ratios as high as $1.3 \mathrm{~m}^{3}$ per $1000 \mathrm{~m}^{3}$. Some high mountains also contain long karstic cavities (up to $90 \mathrm{~km}$ in the Granier massif, Grande Chartreuse, France, Hoblea et al., 2011) and many cave levels (9 in the Têt catchment; 14 in the Siebenhengste; Calvet et al., 2015; Häuselmann, 2002). These stacked caves indicate numerous speleogenetic phases and strong uplift trends. Where these endokarstic galleries contain alluvial sedimentary sequences, they have the potential to record long-term fluvial evolution. Key examples include the European Alps (Styrian Alps: Wagner et al., 2010; Grande Chartreuse massif: Hoblea et al. 2011), the Alpi Apuane, Italy (Piccini et al., 2011), the Sierra Nevada, California (Stock et al., 2004, 2005), and the Hengduan Shan, Tibet (McPhillips et al., 2016).

In the Alps and Pyrenees, TCN burial dating of sediment infills from the highest cave levels frequently yielded Pliocene ages (Häuselmann and Granger, 2005; Wagner et al., 2010; Hoblea et al., 2011; Calvet et al., 2015). The same method, based on the ${ }^{10} \mathrm{Be}$ and ${ }^{21} \mathrm{Ne}$ isotope pair, revealed a Lower Miocene karstification age at the Southeast margin of the Tibetan Plateau at the First Bend (McPhillips et al., 2016). Valley incision and karstification continued during the Quaternary period in European karst regions (Häuselmann and Granger, 2005; Wagner et al., 2010; Calvet et al., 2015), and in China (Qinling: Wang et al., 2004; Northwestern Hunan: 
543 Many high altitude karstified massifs, including the limestone mountains of Europe (e.g. 544 Hughes et al., 2010) and North America (Palmer and Palmer, 1993), were glaciated during 545 Pleistocene cold stages, including MIS 12, 6, and the Younger Dryas. As a result, they evolved 546 into a distinctive 'glaciokarst' landscape (See section 4.3).

\subsection{Karstification in association with rising base and cave level}

The per ascensum model of speleogenesis is initiated by eustasy and climatically-driven aggradation and subsidence (Audra et al., 2001; Figure 5B). The influence of eustatic base level does not typically extend more than $200 \mathrm{~km}$ inland (Antoine et al., 2000). In Europe, one of the most significant examples of rising base level and its impacts on terrestrial landscape change is the Pliocene transgression after the Messinian regression of the Mediterranean basin (e.g. Clauzon, 1978; Audra et al., 2004).

The Languedocian plateaus, incised by the Lower Ardèche canyon (at Saint-Remèze), present a record of rising base and cave level since the Messinian. TCN dating combined with magnetostratigraphy revealed that, following an early phase of karstification during the Messinian regression, subsequent phases of speleogenesis took place during marine and continental aggradation in the Pliocene rias (Mocochain et al., 2009; Tassy et al., 2013, 2014). Rising base level caused flooding of the lower cave levels, which discharged as Vauclusian springs. Pleistocene valley incision led to the progressive draining of horizons situated above base level and the reactivation of caves at the same altitude as the river.

Other cases of base and cave level fluctuations follow a similar evolutionary model (Bruthans and Zeman, 2003; Audra and Palmer, 2011). Several cases of per ascensum speleogenesis by fluvial (or glacial) aggradation occur in Europe, including Podtrat'ová jeskyně in the Moravian karst (Czech Republic, Bruthans and Zeman, 2003) and in the Devoluy mountains, France (Audra \& Palmer, 2011). In the Devoluy chain, the Pleistocene glacial, lacustrine, and glaciofluvial sediment fill increased the elevation of the Gillardes karst springs, and caused the $300 \mathrm{~m}$ high chimney shaft at Puits de Bans to overflow. 
576 Broadly, there are three mechanisms through which Pleistocene glacial activity influenced karst

577 areas. First, in non-glaciated mountains or plateaus areas, incision and karstification were 578 indirectly conditioned by glacial activity, such as the Kentucky Appalachian Plateau (Palmer 579 and Palmer, 1993). Second, in glaciated mountain regions, such as parts of the Dinaric Alps in 580 Montenegro (Hughes et al., 2010; 2011; Adamson et al., 2014), and the Pindus mountains in 581 Greece (Hughes et al., 2006; Woodward et al., 2008), fluvial evolution and karstification were 582 directly influenced by glaciers. Third, some karst areas were covered by ice sheets up to $3 \mathrm{~km}$ 583 thick that developed across much of Northern Eurasia (Eurasian Ice Sheet) and North America 584 (Laurentide Ice Sheet) during Pleistocene glacial phases. The erosional effects of the ice sheets on karst and non-karst landforms and deglacial speleogenesis, are beyond the scope of this paper, which concentrates on karst geomorphology south of the major ice-sheets, and downstream of ice caps and valley glaciers (mechanisms one and two outlined above).

\subsubsection{Indirect impacts of glaciation: the Appalachian plateau of Kentucky, USA}

The Kentucky Appalachian Plateau (c. 2,000 m a.s.1.) is a vast karstified area that contains an extensive sinkhole plain (Pennyroyal Plateau) and the Mammoth Cave Plateau where the famous cave provides a well-preserved example of the indirect influence of glaciers on PlioQuaternary morphologic evolution (Palmer and Palmer, 1993). TCN $\left({ }^{26} \mathrm{Al}\right.$ and $\left.{ }^{10} \mathrm{Be}\right)$ dating of sediments in the five levels of Mammoth Cave, as well as vertical vadose passages, is in accordance with the timing of Pliocene and Pleistocene glaciations of North America (Granger et al., 2001). Major aggradational phases occurred at c. 3.2, 2.3 and $0.8 \mathrm{Ma}$, when large volumes of sediment would have been produced by the ice sheet and delivered downstream via meltwater channels. A major incision phase occurred at c. 1.39 Ma in relation to a drainage change towards the Mississipi catchment when the Ohio river formed along the Southern North-American icesheet margin.

4.3.2. Direct impacts of glaciation: Glaciated limestone mountains: examples from the

Limestone mountains that were glaciated by ice caps or valley glaciers during Pleistocene cold stages, such as the Dinaric Alps, are characterized by a distinctive 'glaciokarst' terrain, which displays features including limestone pavements and bare bedrock surfaces. The presence of glaciers in karst environments can have major impacts on glaciofluvial drainage pathways, and 
610 subsequent karst drainage evolution. On the Orjen massif in western Montenegro, a large ice 611 cap developed during the Pleistocene (MIS 12, 6, 5d-2 and the Younger Dryas, Hughes et al., 612 2010). The configuration of the Orjen massif, with its high altitude (c. 1,800 m a.s.1.) ice 613 accumulation zone, and surrounding depocentres (such as valleys, poljes and dolines), meant 614 that during the major ice advance of MIS 12, ice extended over the plateau, and likely plugged 615 the surface of karst depressions and conduits. Meltwater was delivered directly downstream 616 and largely flowed at the land surface. This is evidenced by the presence of large volumes of 617 glaciofluvial sediments that have been deposited and preserved in large poljes, as terraced 618 valley fills, and as alluvial fans at the margins of the plateau (Adamson et al., 2014; 2016a). 619 One of these alluvial fans, the Lipci fan, extends offshore into the Bay of Kotor. It was deposited 620 subaerially at the southern margins of the Orjen massif during the major glacial phase of MIS 621 12, when sea level in this part of the Mediterranean was up to $140 \mathrm{~m}$ lower than present, and 622 the Bay of Kotor was exposed subaerially (Adamson et al., 2016b). U-series ages of the alluvial 623 deposits at Orjen are consistent with the timing of glacial activity (Hughes et al., 2010). During 624 subsequent cold stages (MIS 6, 5d-2, and the Younger Dryas), the ice cap did not advance 625 beyond the plateau. During these periods, large areas of karst were exposed on the plateau, and meltwater was channeled into subterranean cavities (Adamson et al., 2014). There is only

627 limited evidence of post-MIS 12 alluvium preserved at the surface of the Orjen massif, and 628 incision into the sediment fills is negligible. As a consequence, the oldest (Middle Pleistocene) 629 part of the alluvial record is exceptionally well-preserved, but the youngest archives are not 630 accessible at the surface. The interactions between glacial activity, karst terrain, and fluvial 631 pathways, can therefore be a major control on the Quaternary sedimentary record in such glaciated regions (Stepišnik et al., 2009; Adamson et al., 2014).

\subsection{The particular case of karstified evaporites}

In evaporite rocks, karst systems are sparser and tend to be restricted to relatively drier climate regions due to the restricted availability of moisture. However, in such environments the preservation potential of karst systems is much higher. In some regions of evaporitic bedrock, most commonly gypsum, climate forcing in uplifting areas generates cave levels associated with patterns of river incision and aggradation. In the Northern Apennines, Italy, especially in

641 the region of Emilia Romagna, the Re Tiberio cave system is hosted in Messinian gypsum 642 (Columbu et al., 2015). Gypsum is much more soluble than limestone, and cave levels form 643 very rapidly. 
644 Two significant examples of karstified evaporites also exist in Spain, in the Sorbas basin, 645 Southeastern Spain, and in the Gállego valley, in the central Ebro Basin, with cave levels and 646 subsidence areas respectively (Calaforra and Pulido-Bosch, 2003).

\subsubsection{Cave levels in karstified evaporites}

649

650 The Sorbas basin, Southeast Spain, contains an interstratal karst system formed within 651 intercalated Messinian gypsum and marls (Calaforra \& Pulido-Bosch, 2003; Figure 6A). At 652 first, the gypsum karst evolved under phreatic conditions during the early Pleistocene, enabling the formation of small conduits. Subsequently, mechanical erosion occurred under vadose conditions. Increased incision, as a consequence of rapid Plio-Pleistocene uplift (>80-160 $\mathrm{mm} / \mathrm{ka}$; Mather, 2000) allowed an eastward capture of the Upper Aguas river system at c. 70 $\mathrm{ka}$ (based on U series dating of river terrace calcretes, Candy et al., 2005, Harvey et al., 2014). Dated pre-capture terraces represent the former southern drainage system of the Rio Aguas, prior to the river capture event, enabling incision rates to be calculated (Stokes et al., 2002). In fact, the capture leads to a 10 fold increase in incision rates, driven by the $\sim 90 \mathrm{~m}$ base level drop that it initiated (Stokes et al., 2002). This incision led to the development of further cave levels. Karst tributaries that were connected to the Aguas channel at the surface, were protected from enhanced incision due to the development of the cave network (Mather 2000). Headward incision in the Upper Aguas catchment induced a lowering of the piezometric level in the Sorbas basin. Subterranean erosion processes, largely concentrated into the marl strata, occurred under vadose conditions (Calaforra \& Pulido-Bosch, 2003), and these processes continue at the present day.

\subsubsection{Subsidence in evaporite rock areas}

Bruthans and Zeman (2003) identified a suit of features typical of salt karst terrain, including broad and low caves shaped by subterranean meandering streams, and the development of large subterranean alluvial fans, due to the high solubility of salt $(\mathrm{NaCl})$. Apart from these forms, a key feature of evaporite karst (e.g. gypsum karst) is the incomplete record of valley evolution due to high solubility and enhanced dissolution and subsidence. A number of examples exist worldwide, most notably in Spain (Benito et al., 1998, 2010; Figure 6B). In the Gállego valley, in the central Ebro Basin, Northern Zaragoza, 12 stepped terraces (2-5 m thick) were mapped 
downstream thickening of the alluvial formations, as well as multi-scale karstic depressions and syn- and post-sedimentary deformations, such as collapses, reverse faults, and marl-clay diapiric structures, reflect the dissolution of Cenozoic evaporitic bedrock. Palaomagnetic and

681 OSL dating revealed two main periods of subsidence and associated alluvial aggradation: the 682 first (represented by terraces T2, T3, and T4) began in the Early Pleistocene (Benito et al., 683 1998). The second occurred during MIS 6, primarily when glaciers were present in the 684 Pyrenees. A later phase also occurred during the Warthe Advance, a later part of MIS 6 (155$140 \mathrm{ka})$, as a result of high discharge delivered by the upper catchment of the Gállego River

In the Eastern Cinca and Segre catchments of the Ebro Basin, Lucha et al. (2012) identified a phase of dissolution subsidence and halokinetic uplift along the evaporitic core of the Barbastro-Balaguer Anticline. Eight of the nine fluvial terraces were affected by dissolutioninduced synsedimentary subsidence, by dissolution-induced post-sedimentary subsidence, or by deformation due to salt flow, especially the upper Pleistocene terrace 4 of the Cinca River. OSL ages obtained in the alluvial sediments of this backtilted terrace indicated a minimum uplift rate of $0.3 \mathrm{~mm} / \mathrm{a}$ (Lucha et al., 2012). Moreover, deposits of the highest terrace levels reach over $100 \mathrm{~m}$ thickness in the Segre catchment, in basins generated by dissolution-induced synsedimentary subsidence.

\section{Discussion}

\subsection{Variability of incision rates in karst fluvial systems}

Based on chronological evidence from karstic fluvial sedimentary fills and secondary carbonate forms, such as travertine and calcrete, long-term regional incision rates can be securely constrained. In fact, numerical dating highlights the variability in space and time of river incision rates. Incision rates are highest in high mountains (>2,000 $\mathrm{m}$ a.s.1.), exceeding 100 mm/ka in the Alps (Hobléa et al., 2011; Häuselmann \& Granger, 2005; Wagner et al., 2010) or in China (especially on the southeast margin of the Tibetan Plateau, McPhillips et al., 2016). Incision rates are lower $(<100 \mathrm{~mm} / \mathrm{ka})$ in the plateaus and low mountain range areas $(200-2,000$ $\mathrm{m}$ a.s.1.), such as the Eastern Paris Basin (Harmand \& Cordier, 2012), the Languedocian plateaus (Ambert \& Ambert, 1995; Camus, 1997; Audra et al., 2001), the Duero basin (Moreno et al., 2012; Ortega et al., 2013), Swabian Alps (Abel et al., 2002), or the Eastern Pyrenees 
712 (Calvet et al., 2015). The lowest incision rates (typically $<10 \mathrm{~mm} / \mathrm{ka}$ ) are measured in 713 Palaeozoic crustal provinces, such as the Southeastern part of Australia (Webb et al., 1992) or 714 on the Appalachian plateau (Granger et al., 2001).

716 Most of the time, higher incision rates are related to periods of stronger uplift, such as in the 717 Styrian Alps or the Western American Sierra Nevada, where Miocene uplift rates reached 140 $718 \mathrm{~mm} / \mathrm{ka}$ (Stock et al., 2005; Wagner et al., 2010). Where karstification and fluvial dynamics 719 have been studied in particular detail, it is possible to identify multiple uplift phases during the 720 Cenozoic era. This is the case in the Languedocian plateaus where karstic and valley evolution corresponded to several uplift pulses since the Cretaceous period (Séranne et al., 2002); the last pulse occurring during the Middle to Late Miocene. The onset of accelerated incision is related to Pliocene and Pleistocene tectonic uplift and climate change, in the Sierra Nevada (from 3 and 1.5 Ma; Stock et al., 2005), in the middle Ardèche valley (since $2 \mathrm{Ma}$; Audra et al., 2001) or in the Eastern Pyrenees (since the beginning of the Pleistocene; Calvet et al., 2015). Variations in tectonically- and climatically-driven incision rates are conditioned locally by geomorphology and fluvial behavior, such as river capture. In the Styrian Alps, strong incision of the Mur River, from 4 to 2.5 Ma was connected with an extension of the Mur catchment following river drainage change (Wagner et al., 2010). Decreased incision during the Quaternary corresponded to fluvial aggradation during Pleistocene cold periods and reduced potential for bedrock entrenchment. Short-term increase in incision rate in the Siebenhengste at $800 \mathrm{ka}$ has been related to a change in flow direction from the Eriz valley to the south, to the Aare valley in the north (Häuselmann \& Granger, 2005). Similar short-term changes in incision rate are evident in the Mammoth Cave record, where an incision event at c. $1.4 \mathrm{Ma}$ has been correlated with headward erosion in the Green River valley, after the formation of the Ohio River, at the end of an ice-sheet advance (Granger et al., 2001).

Delayed response between tectonic uplift and resulting fluvial incision can also be discerned from the karst-fluvial archive. This is the case in the Ardenne massif where ${ }^{10} \mathrm{Be}$ dating highlighted diachronous river incision from the lower Meuse valley at the northern rim of the Ardenne to its intra-massif (sub-) tributaries, i.e. Belle-Roche in the Amblève valley (Rixhon et al., 2011, 2014). However, rates of knickpoint retreat are variable, and depend on many factors, including climate, discharge, lithology, tectonics and time (Whittaker \& Boulton, 2012). These controls are translated into the morphosedimentary record as spatial variations in the timing of uplift, valley incision, aggradation, and karstification. In the Upper Yangzi 
catchment, cosmogenic nuclide ages suggest a considerably delayed response (c. $20 \mathrm{Ma}$ ) between Late Eocene uplift (Hoke et al., 2014) and Miocene incision (from 18 to $9 \mathrm{Ma}$ ), such that valley incision is not a useful proxy for surface uplift (McPhillips et al., 2016).

\subsection{Models of valley evolution and karstification}

At the regional scale (e.g. across the Mediterranean basin), eustatic, isostatic, tectonic and climatic factors, largely explain the rise or fall of base and cave levels. These drivers do not influence hypogenic caves and ghost rocks (isovolumetric weathering with very low flow) because these types of speleogenesis are not connected to a fluvial base level. However, uplifted hypogenic and ghost rock karsts can be reactivated, as cryptokarsts (when karstification occurs under an impervious sedimentary cover) or palaeokarsts, when they can be influenced by base and cave level change (e.g. Wealdian: continental Infra-Cretaceous (Vergari \& Quinif, 1997; Jaillet et al., 2004). In most karst regions, geomorphological evolution consists of valley incision and per descensum speleogenesis. Over Quaternary timescales, this model is underpinned by climate change, since tectonic uplift and subsidence change over much longer geological time spans. Thus, Quaternary glacial and interglacial cycles are recorded in terraces and caves by aggradation, incision, or concretion phases (Antoine, 1994; Quinif, 2006; Columbu et al., 2015).

At the catchment scale, Pleistocene climatic cycles and geomorphological factors influenced fluvial and karstic environments. In many catchments, river incision chiefly occurs during coldto-warm or warm-to-cold climatic transitions, in accordance with regional climate change (Antoine, 1994; Bridgland et al., 2009). Underground streams adjust to falling base level by incising new passages. However, there is evidence that per descensum speleogenesis also depends on the timing of valley incision, as well as geological factors such as (i) the degree of bedrock karstification (Abel et al., 2002), (ii) alternating pervious and impervious strata causing perched karsts (Devos et al., 2015, Figure 4A level a) and iii) underground karstic flows towards a lower elevation river in a neighbouring hydrographic basin or in the downstream position of the same river (Losson, 2003). As a consequence, numerous interactions between fluvial evolution and karstification can exist. We therefore propose four local to regional models of Quaternary geomorphological evolution from different settings: 1) Eastern Pyrenees, in limestone rocks, 2 and 3) low limestone plateaus of the Eastern Paris Basin and 4) a rapidly- 
uplifted gypsum area in the Northern Apennines, Italy (Losson, 2003; Antoine et al., 2006; Hez et al., 2015; Colombu et al., 2015).

\subsubsection{A conceptual model of valley scale karstic and fluvial development: river terrace records in the Têt basin (Eastern French Pyrenees)}

On the basis of river terrace records from the Eastern French Pyrenees (Calvet et al., 2015; Hez et al., 2015), a valley-scale conceptual model of karst drainage evolution is presented in Figure 7. This reflects changes in karst genesis, evolution, and abandonment as well as fluvial incision into bedrock, sediment aggradation, and terrace incision/abandonment. This model is based on cavities in the Têt basin, especially in the Devonian limestones syncline of Villefranche, where nine horizontal conduits exist up to $1,000 \mathrm{~m}$ above the present valley floor (Hez et al., 2015; Calvet et al., 2015). The two lowest karstic tubes contain rich morphologies of sediment fill and corrosion forms, which can be explained by the succession of three genetic karstic phases (Figure 7A, C). In phase 1, the presence of phreatic caves indicates syngenetic karstification below base level during or after valley incision. In phase 2, bench walls and the corroded ceiling of the horizontal conduit indicate aggradation at the valley bottom leading to progressive and synchronous base-level rise during a paragenetic phase. During phase 3 , funnel shaped conduits cutting down into the horizontal tubes highlight a period of renewed incision ("trepanning", Jaillet et al., 2004). This suggests a diachronic evolution of the caves with: a) lowering of the base-level inducing downstream incision of the paragenetic stage sediments. Thus, ancient horizontal conduits shaped in the flooded zone evolve downstream in the vadose zone where the cave deposits are partially reworked (see phase 1); b) formation of bench walls in the middle part of the galleries; and c) deposition of a cave fan delta upstream. Indeed, a strong hydraulic gradient (1/1000) and flooding on the perched valley floor causes upstream transport and deposition of coarse alluvium in karstic caves. In a last stage d), headward erosion along the valley axis induces fluvial incision of the alluvial plain and underlying bedrock, and entrenchment of the cave fill. Beneath the valley floor, a karstic drain is initiated in the flooded zone (Figure 7B).

One must note that this model of karstic drain evolution and the relationships between valley and karstic development during a Pleistocene climatic cycle is not valid when underground flow is diverted to stream capture or piracy (see below, Figure $8 \mathrm{~B}$ ). Thus, in the capture area of the 
812 Moselle river by the Meurthe (Losson, 2003), the caves of Pierre-la-Treiche show that the

813 endokarstic networks are not correlated in elevation with the Moselle terraces.

814

5.2.2. Two conceptual models of regional karstic and fluvial development in low limestone plateaus: cave records

818 In limestone plateaus, alluvial stepped terraces and tiered cave infills record successive 819 Milankovitch cycles of palaeoenvironmental change (Figure 8). In both models (Figure 8A and 820 8B), two positions are distinguished based to the type of speleogenesis. Figure 8A shows the evolution of a plateau karst where the caves are in connection with the valley bottom. Figure $8 \mathrm{~B}$ presents a valley karst. The lower caves, situated below the water table, are in connection with the base level of another valley which is located below the water table, as in Pierre-laTreiche (Losson et al., 2006). Figure 8B3 presents a valley karst where underground flows occur between zones of karstic losses and resurgences along the same valley, such as the upper Meuse upstream of Neufchâteau, Eastern Paris basin (Losson, 2003).

In both models, stage 1 corresponds to an interglacial period with pedogenesis and silt deposition in river systems and caves. Biological $\mathrm{CO}_{2}$ allows speleothem, travertine and tufa growth, especially in warm environments or in chalk Cretaceous catchments where thick tufa deposits occur (Antoine et al., 2006, Figure 8A). During stage 2, at the onset of climate cooling, the progressive disappearance of forests leads to soil erosion on the slopes, lateral erosion in the meandering valleys, and headward erosion of the steep slopes of the karstic massif (Antoine, 1994). As a consequence, cave entrances become disconnected from the valley bottom in a plateau karst (Figure 8A). There is little or no speleothem growth in vadose caves and fine clastic deposits (from soil erosion) are deposed in flooded cavities. Lower flooded caves are situated below the water table in relation to neighbouring valley (such as the Palaeo-Meurthe valley, Figure 8B). In the cold period (stage 3), for example in the Moselle valley (Figure 8B), the river entrenches into the bedrock, above the former flooded caves connected with the Palaeo-Meurthe river. In stage 4, during full glacial conditions (such as the Last Glacial Maximum, MIS 2), coarse alluvium, originating from the glaciated Vosges massif, was deposited by a braided river in the valley bottom. This material was also deposited in the lower elevation flooded or vadose caves (Losson et al., 2006). In fact, glaciated karst regions where a major glacial advance occurs generates large volumes of sediment that are deposited in karst cavities at the surface and subsurface, leading to major phases of aggradation 
(e.g. Lewin \& Woodward, 2009; Adamson et al., 2014, 2016a and b). No speleothem formation occurs during full glacial conditions (Fairchild and Baker, 2012).

When large volumes of alluvium are deposited on the valley floor, they can fill caves that are situated (almost) at the same altitude as the river (Figure 8A), such as the Middle Pleistocene filling of the Belle-Roche cave in the Ardenne massif (Rixhon et al., 2014). Some authors have highlighted the difference between wet glacial periods characterized by sediment-laden rivers, and dry cold periods with reworked loess, for example in Belgian caves, close to the former margins of the Fennoscandian ice sheet (Quinif, 2006). Where caves have become filled, they display evidence of a complex geomorphological evolution, with successive phases of aggradation and incision (Quinif \& Maire, 1998).

The wide caves of Pierre-la-Treiche, filled with coarse grained alluvium (Figure 8B) indicate a speleogenetic phase during an interglacial period, before the deposition of alluvium in the subsequent glaciation. However, the horizontal cave levels of the (epi)phreatic zone, which correspond to stable base levels without tectonic uplift, require a minimum formation time by solutional processes of 10-40 ka (Ford \& Williams, 1989). The time period between two Quaternary glaciations (MIS 5e, c, a) is thus long enough for dissolution processes to excavate the horizontal tubes. During the subsequent interglacial, new flooded caves were formed at the bottom of the valley where tufa deposits can develop (Antoine et al., 2006; Dabkowski et al., 2011; Figure 8A). Today, at Pierre-la-Treiche, the entrenched valley of the Moselle is situated below the vadose caves (Losson, 2003; Cordier et al., 2006) where speleothems have grown since $300 \mathrm{ka}$, spanning several interglacial and interstadial periods (Losson, 2003, Losson et al., 2006; Pons-Branchu et al., 2010).

\subsubsection{Model of climate-driven speleogenesis of gypsum caves}

Figure 9 presents a model of climate-driven river incision and karstification based on the multilevel gypsum cave systems of the Re Tiberio (Fig. 1) situated in the moderately-rapidly uplifted Northern Apennines, Italy (Columbu et al., 2015). This Italian karstified area presents a more relevant model than the Spanish karsts, where the subsidence is irregular in time and space (Gállego valley) or where the geomorphological evolution is accelerated by a river capture event (Rio Aguas, Sorbas basin, see 4.4). Mostly, in the Re Tiberio valley, dating speleothems 
880

881

882

883

884

885

886

887

888

889

890

891

892

893

894

895

896

897

898

899

900

901

902

903

904

905

906

907

908

909

910

911

912

calcite speleothems from the three cave levels, situated at 340, 215, and $190 \mathrm{~m}$ a.s.1., revealed growth phases during the MIS 5e, MIS 5d-c (Dansgaard-Oeschger cycle 24) and MIS 5b-a (DO cycles 22 to 20), respectively. The ages suggest rapid entrenchment during cold periods, because uplift rates had reached c. $1 \mathrm{~mm} / \mathrm{yr}$ since the end of the Middle Pleistocene (Columbu et al., 2015).

This model presents significant differences with previous conceptual models (see Figs 7 and 8), because horizontal cave levels formed during cold periods. Karst evolution was rapid, especially during wetter phases, due to increased bedload (Figure 9B2, 9B3, 9B4). Valley aggradation led to the infilling of cave passages and a paragenetic karstification due to slowly rising base level. During the subsequent warm period, decreased bedload initiated incision into the cave sediments, but karstification was slow (Figure 9A, 9B5). The key similarities with the models presented in Figures 7 and 8, are that carbonate speleothems grew during wet and warm interglacials or interstadials (MIS 5e, 5d-a, 5b-a, figure 9A, 9B1) and valley incision occurred at cooling transitions due to high stream discharge and low bedload concentrations (figure 9B2).

\subsubsection{Diverse models of karstic and valley evolution}

The four models outlined above present idealised scenarios, based on existing evidence, but more complex models of fluvial and karstic evolution can occur in response to local to regional conditions. Thus, successive aggradation or erosion phases can occur over multiple cold periods. These can be recorded in the same cave level, as in the Pierre-Saint-Martin caves in the French Pyrenees (Quinif \& Maire, 1998). On the other hand, tiered caves can be filled with deposits of the same age, as in the Mammoth cave, USA (Granger et al., 2001). Establishing the model of karst and valley evolution in different settings relies on the number of cave levels and river terrace surfaces in a connected valley. However, the number of cave passage levels present in karst landscapes is commonly lower than the number of $100 \mathrm{ka}$ cycles that have occurred over the last $1 \mathrm{Ma}$ of the Quaternary. This suggests that karst-fluvial systems might record only the major climate changes ('supercycles' of Kukla, 2005; Bridgland et al., 2009) or/and variations in uplift rate.

\section{Conclusion}


913 For two decades, analysis of river systems in karstic areas, including the wider application of

914 dating methods, such as cosmogenic nuclide dating of cave infills, have provided a better 915 understanding of geomorphological evolution over the Cenozoic era, especially during the 916 Quaternary. Alluvial records in karst terrain, especially in European karst catchments, where 917 the sedimentary records are particularly well preserved compared to their sub-aerial 918 counterparts, now provide a reliable record of landscape evolution that can be effectively tied 919 to wider, regional morphosedimentary archives.

921 Evidence indicates that many factors, including uplift, eustatic fluctuations, climatic conditions and fluvial dynamics (e.g. knickpoint retreat, increased channel flow and/or sediment load, and stream piracies), can play a major role in speleogenesis and geomorphological evolution. Data reviewed here have allowed us to propose a four-fold typology of the relationship between fluvial evolution and karstification: 1) karstification in association with base and cave level 926 lowering, i) in low elevation and tectonically-stable cratonic area, ii) on low altitude plateaus 927 (<500 $\mathrm{m}$ a.s.1.), iii) on high altitude plateaus and low mountain ranges (500 - 2,000 a.s.1.), where long-term records of fluvial incision and karstification are present; iv) in high mountain regions (>2,000 m a.s.1.), 2) karstification in association with rising base and cave level, 3) Pleistocene incision and karstification in association with glaciation, and 4) the particular case of karstified evaporites. In, gypsum and salt speleogenesis is characterized by rapid dissolution and subsidence. In European catchments, gypsum cave enlargement has occurred during cold climate periods, while limestone caves formed during warm interglacial or interstadial phases.

934 However, in limestone rocks, the bulk of karstic cave fills correspond to cold periods, with thick, clastic sediments deposited under glacial conditions. Speleothems and tufa deposits are formed chiefly during interglacial periods. This demonstrates that, over Quaternary timescales, climate plays an important role in karst processes. The regional and local setting determines the modes of valley evolution and karstification, and the geomorphological framework plays a triggering factor to initiate speleogenesis.

941 In addition, our synthesis is used to propose four models of fluvial and karst evolution, from 942 different settings: 1) in the Eastern Pyrenees, in limestone rocks, 2 and 3) in low elevation 943 limestone plateaus of the Eastern Paris Basin, and 4) a rapidly-uplifted gypsum area in the 944 Northern Apennines, Italy. 
946 Future research should focus on improved reliability and application of dating methods, 947 because in many cases, numerical dating is not possible, due to a lack of alluvial sequences such as fluvial terraces or sedimentary fills within karstic caves and surface depressions (such as poljes and dolines). Even if alluvium is preserved in karstic terrain, it may not contain sufficient siliceous content for OSL dating, or secondary carbonate concretions, such as travertine or calcrete, for U-series dating. Moreover, U-series dating is further complicated by the ingrowth of younger calcite into pre-existing sediments. Alluvial sequences might also bear the imprint of sediment reworking, meaning that the sedimentary sequence is not indicative of primary formation mechanisms. Further research should also include other karstic regions, especially low latitude regions, as well as arid regions, around the Mediterranean Sea, to enhance our understanding of karstic processes in other global regions.

\section{References}

960

Abel, T., Hinderer, M., Sauter, M., 2002. Karst genesis of the Swabian Alb, south Germany,since the Pliocene. Acta Geologica Polonica, 52, 1, 43-54.

Adamson, K.R., Woodward, J.C., Hughes, P.D., 2014. Glaciers and rivers: Pleistocene uncoupling in a Mediterranean mountain karst. Quaternary Science Reviews 94, 28-43. Adamson, K., Candy, I., Whitfield, L., 2015. Coupled micromorphological and stable isotope analysis of Quaternary calcrete development. Quaternary Research, 84 (2), 272-286. Adamson, K. R., Woodward, J. C., Hughes, P. D. 2016a. Middle Pleistocene glacial outwash in poljes of the Dinaric karst. In: Gao, Y. and Alexander Jr, E.C (Eds) Caves and Karst Across Time. Geological Society of America, Vol. 516, 247-263. Pleistocene glaciation, alluvial fan development and sea-level changes in the Bay of Kotor, Montenegro. In: Hughes, P. D. and Woodward, J. C. (Eds) Quaternary Glaciation in the Mediterranean Mountains Geological Society, London, Special Publications, 433, SP433-13. Ambert, M. and Ambert P., 1995. Karstification des plateaux et encaissement des vallées au cours du Néogène et du Quaternaire dans les Grands Causses méridionaux (Larzac, Blandas). Géologie de la France, 4, 37-50. erosional surfaces determined by cosmogenic nuclides in cave sediments. Earth Surface 
980 Antoine, P., 1994. The Somme Valley terrace system (northern France): a model of river 981 response to Quaternary climatic variations since 800,000 BP. Terra Nova 6, 453-464.

982 Antoine, P., Lautridou, J.P, Laurent, M., 2000. Long-term fluvial archives in NW France: 983 response of the Seine and Somme rivers to tectonic movements, climatic variations and sea984 level changes. Geomorphology 33, 3-4,183-207.

985 Antoine, P., Limondin-Lozouet, N., Auguste, P., Locht, J.L., Galheb, B., Reyss, J.L., Escude, 986 E., Carbonel, P., Mercier, N., Bahain, J.J., Falguères, C., Voinchet, P., 2006. Le tuf de Caours 987 (Somme, France): mise en évidence d'une séquence éémienne et d'un site paléolithique associé. 988 Quaternaire 17,4, 281-320.

989 Audra, P., Ed., 2010, Grottes et karsts de France. Karstologia Mémoires, n 19, 44-45.

990 Audra, P., 2010, La spéléogenèse épigène. In: Audra, P., Ed, 2010. Grottes et karsts de France. 991 Karstologia Mémoires, 19, 44-45.

992 Audra, P., Camus, H., Rochette, P., 2001. Le karst des plateaux jurassiques de la moyenne 993 vallée de l'Ardèche : datations par paléomagnétisme des phases d'évolution plio-quaternaire 994 (aven de la Combe Rajeau). Bull. Soc. Géol. France, 172, 1, 121-129.

995 Audra, P., Mocochain, L., Camus, H., Gilli, É., Clauzon, G., Bigot, J.-Y., 2004. The effect of 996 the Messinian Deep Stage on karst development around the Mediterranean Sea. Examples from 997 Southern France. Geodinamica Acta, 17, 6, 27-38.

998 Audra P., Bini A., Gabrovsek F., Häuselmann P., Hobléa F., Jeannin P.Y., Kunaver J., 999 Monbaron M., Sustersic F., Tognini P., Trimmel H., Wilberger A., 2007. Cave and karst 1000 evolution in the Alps and their relation to paleoclimate and paleotopography. Acta Carsologica $100136-1,53-67$.

1002 Audra, P., Mocochain, L., Bigot, J.-Y., Nobécourt, J.-C., 2009. The association between bubble 1003 trails and folia: a morphological and sedimentary indicator of hypogenic speleogenesis by 1004 degassing, example from Adaouste Cave (Provence, France). International Journal of 1005 Speleology, Bologna, 38, 2: 93-102.

1006 Audra, P. and Palmer, A.N., 2011. The pattern of caves: controls of epigenic speleogenesis. 1007 Géomorphologie, 4, 359-378.

1008 Audra, P. and Palmer, A.N., 2013. The vertical dimension of karst: controls of vertical cave 1009 pattern. In: Shroder, J. (Editor in chief), Frumkin, A. (Ed.), Treatise on Geomorphology. 1010 Academic Press, San Diego, CA, 6, Karst Geomorphology, 186-206.

1011 Bastin, B. and Gewelt, M., 1986. Analyse pollinique et datation ${ }^{14} \mathrm{C}$ de concrétions 1012 stalagmitiques holocènes : apports complémentaires des deux méthodes. Géographie physique 1013 et Quaternaire, 40, 2, 185-196. 
1014 Bazalgette, L. and Petit, J.P., 2005. Fold amplification and style transition involving fractured

1015 dip-domain boundaries; buckling experiments in brittle paraffin wax multilayers and 1016 comparison with natural examples. Geological Society Special Publications (2007) 270: 1571017169

1018 Benito, G., Pérez-González, A., Gutiérrez, F., Machado, M.J., 1998. River response to 1019 Quaternary subsidence due to evaporite solution (Gállego River, Ebro Basin, Spain). 1020 Geomorphology 22, 243-263.

1021 Benito, G., Sancho, C., Peña, J.L., Machado, M.J., Rhodes, E.J., 2010. Large-scale karst 1022 subsidence and accelerated fluvial aggradation during MIS6 in NE Spain: climatic and 1023 paleohydrological implications. Quaternary Science Reviews 29, 2694-2704.

1024 Bigot, J.-Y. and Audra, P., 2010. Les cavités parakarstiques des grès et des conglomérats. In: 1025 Audra, Ph., ed, 2010. Grottes et karsts de France. Karstologia Mémoires, 19, 84-85.

1026 Bridgland, D. and Westaway, R., 2007. Climatically controlled river terrace straircases: A 1027 wordwise Quaternary phenomenon. Geomorphology, 98, 285-315.

1028 Bridgland, D., Westaway, R., Cordier, S., 2009. Les causes de l'étagement des terrasses 1029 alluviales à travers le monde. Quaternaire, 20, 4, 5-23.

1030 Bruthans J. and Zeman O., 2003. Factors controlling exokarst morphology and sediment 1031 transport trough caves: comparison of carbonate and salt karst. Acta Carsologica 32-1, 83-99.

1032 Bruxelles, L., Astruc, J.-L., Simon-Coinçon, R., Ciszak, R., 2013. Histoire des paysages et 1033 Préhistoire : l'apport de la connaissance géomorphologique du Quercy pour la compréhension 1034 de l'environnement paléolithique. Actes de la session C67, XVème Congrès mondial de 1035 l’UISPP, Lisbonne, sept. 2006, PALEO, supplément 4, 21-36.

1036 Buffard, R. and Fischer, H., 1993. Les gisements de fer de la région de Kisanga (Shaba 1037 méridional, Zaïre), colmatages d'un paléokarst du Protérozoïque supérieur, Karstologia, 21, 51103855.

1039 Calaforra, J.M. and Pulido-Bosch, A., 2003. Evolution of the gypsum karst of Sorbas (SE 1040 Spain). Geomorphology, 50, 1, 173-180.

1041 Calvet, M., Gunnell, Y., Braucher, R., Hez, G., Bourlès, D., Guillouc, V., Delmas, M., ASTER 1042 Team, 2015. Cave levels as proxies for measuring post-orogenic uplift: Evidence from 1043 cosmogenic dating of alluvium-filled caves in the French Pyrenees, Geomorphology, 246, 6171044633.

1045 Campy, M., 1982. Le Quaternaire franc-comtois. Essai chronologique et paléoclimatique. 1046 Thèse d'État, 575 p., Besançon. 
1047 Camus, H., 1997. Formations des réseaux karstiques et creusement des vallées : l'exemple du 1048 Larzac méridional, Hérault, France. Karstologia, 29, 1, 23-42.

1049 Camus, H., 2010. L'aven de la Leïcasse, un modèle de spéléogenèse des Causses méridionaux.

1050 In: Audra, P., Ed, 2010. Grottes et karsts de France. Karstologia Mémoires, 19, 310-311.

1051 Candy, I., Black, S., Sellwood, B.W., 2005. U-series isochron dating of immature and mature 1052 calcretes as a basis for constructing Quaternary landform chronologies for the Sorbas basin, 1053 southeast Spain. Quaternary Research, 64 (1), 100-111.

1054 Clauzon, G., 1978. The Messinian Var canyon (Provence, Southern France). Paleogeographic 1055 implications. Marine Geology 27, 3-4, 231-246.

1056 Columbu, A., De Waele, J., Forti, P., Montagna, P., Picotti, V., Pons-Branchu, E., Hellstrom, 1057 J., Bajo, P., Drysdale, R., 2015. Gypsum caves as indicators of climate-driven river incision 1058 and aggradation in a rapidly uplifting region. Geology, 43, 6, 539-542.

1059 Cordier, S., Harmand, D., Frechen, M., Beiner, M., 2006: Fluvial system response to Middle 1060 and Upper Pleistocene climate change in the Meurthe and Moselle valleys (Eastern Paris Basin 1061 and Rhenish Massif). Quaternary Science Reviews, 25, 1460-1474.

1062 Cordy, J.-M., Bastin, B., Demaret-Fairon, M., Ek, C., Geeraerts, R., Groessens-Van Dyck, 1063 M.C., Oze, A., Peuchot, R., Quinif, Y., Thorez, J., Ulrix-Closset, M., 1993. La grotte de la 1064 Belle-Roche (Sprimont, Province de Liège) : un gisement paléontologique et archéologique 1065 d'exception au Bénélux. Bull. de la Classe des sciences, Académie royale de Belgique, 1-6, $1066 \quad 165-186$.

1067 Couchoud, I., 2008. Les spéléothèmes, archives des variations paléoenvironnementales. 1068 Quaternaire, 19, 4, 255-274.

1069 Dabkowski, J., Limondin-Lozouet, N., Antoine, P., Marca-Bell, A., Andrews, J., 2011. 1070 Enregistrement des variations climatiques au cours des interglaciaires d'après l'étude des 1071 isotopes stables de la calcite de tufs calcaires pléistocènes du nord de la France : exemple des 1072 séquences de Caours (SIM 5e ; Somme) et de La Celle-Sur-Seine (SIM 11 ; Seine-et- Marne). 1073 Quaternaire, 22, (4), 275-283.

1074 Dabkowski, J., Limondin-Lozouet, N., Anders, J., Marca-Bell, A., Antoine, P., 2016. Climatic 1075 and environmental variations during the Last Interglacial recorded in a Northern France Tufa 1076 (Caours, Somme Basin). Comparisons with regional to global records. Quaternaire, 27, (3), $1077 \quad 249-261$.

1078 Delannoy, J.-J., 1982. Les variations spatio-temporelles de la corrosion karstique dans un 1079 massif de moyenne montagne : le Vercors. Revue de géographie alpine, 70, 3, 241-255. 
1080 Delannoy, J.-J., 1997, Recherches géomorphologiques sur les massifs karstiques du Vercors et 1081 de la transversale de Ronda (Andalousie). Les apports morphogéniques du karst. Thèse de 1082 doctorat d'état en géographie / Université Joseph Fourier / Grenoble 1, 706 p.

1083 Delannoy, J.-J., Perrette, Y., Destombes, J.-L., Peiry, J.-L., 1999. Excursion 4 : le Vercors. 1084 Itinéraire : Ste Eulalie-en-Royans - Grands Goulets - Val médian - Gorges de la Bourne 1085 Grottes de Choranche. Cahiers savoisiens de Géographie, [field excursions guide of the 1086 European Conference "Karst 99", Grands Causses - Vercors, 10-15 September 1999], 1087 Université de Savoie: 75-108.

1088 Devos, A., Lejeune, O., Chopin, E., 2007. Structural control on surface flow in karstic 1089 environnement, Geodinamica Acta, 20/6, 393-402.

1090 Devos, A., Sosson, C., Fronteau, G., Lejeune, O., 2009. Les tuffières de Vormy et des 1091 Fontinettes (Aisne, Marne, France): marqueurs de la faible karstification des calcaires lutétiens 1092 de l'Est du Bassin parisien? Karstologia 54, 37-48.

1093 Devos, A., Chalumeau, Sosson, C., Fronteau, G., Turmel, A., Lejeune, O., 2011: La 1094 fantômisation des calcaires lutétiens du bassin de Paris - Apport des carrières souterraines, 1095 Karstologia 58, 15-28.

1096 Devos, A., Bollot, N., Chalumeau, L., Fronteau, G., Lejeune, O., 2015. Impact of lateral 1097 variations of geologic facies on water resources in homogeneous basins - Example of tertiary 1098 plateaus in the Paris Basin. Geodinamica acta, 27, 1, 15-24.

1099 Dunai, T., 2010. Cosmogenic nuclides - Principles, Concepts and Applications in the Earth 1100 Surface Sciences, Cambridge University Press, 187 p.

1101 Ek, C., 1961. Conduits souterrains en relation avec les terrasses fluviales. Annales de la Société géologique de Belgique, Liège, t. LXXXIV, 313-340.

1103 Fairchild, I. J. and Baker, A., 2012. Speleothem Science: From Process to Past Environments, 1104 Wiley-Blackwell, $450 \mathrm{p}$.

1105 Ford, D.C. and Ewers, R.O., 1978. The development of limestone cave systems in the 1106 dimensions of length and depth. International Journal of Speleology, 10, 213-244.

1107 Ford, D. and Williams, P., 1989. Karst geomorphology and hydrology, Unwin Hyman, 601 p.

1108 Frank, N., Kober, B., Mangini, A., 2006. Carbonate precipitation, U-series dating and U1109 isotopic variations in a Holocene travertine platform at Bad Langensalza - Thuringia Basin, 1110 Germany. In: Tufs calcaires et travertins quaternaires: morphogenèse, biocénoses, paléoclimats 1111 et implantations paléolithiques. 2ème partie. Quaternaire, 17, 4, 333-342.

1112 Gabrovšek, F., Häuselmann, P., Audra, P., 2014. 'Looping caves' versus 'water table caves': 1113 the role of base-level changes and recharge variations in cave development. Geomorphology 
204, 683-691.

1115 Gázquez, F., Calaforra, J.M., Evans, N.P., Hodell, D.A., 2016. Using stable isotopes ( $\delta 18 \mathrm{O}$ and $\delta \mathrm{D})$ of gypsum hydration water to unravel the mode of gypsum speleothem formation in semiarid caves. EGU General Assembly 2016, held 17-22 April, 2016 in Vienna Austria, p.8911.

1118 Gilli, E., 2010. Les grands volumes karstiques souterrains. In: Audra, P., Ed, Grottes et karsts 1119 de France. Karstologia Mémoires, 19, 54-55.

1120 Granger, D.E., 2014. Cosmogenic Nuclide Burial Dating in Archaeology and 1121 Paleoanthropology. In: Treatise on Geochemistry: Second Edition. Elsevier Ltd, 81-97.

1122 Granger, D.E., Kirchner, J.W., Finkel, R.C., 1997. Quaternary downcutting rate of the New 1123 River, Virginia, measured from differential decay of cosmogenic 26Al and 10Be in cave1124 deposited alluvium. Geology, 25, 2, 107-110.

1125 Granger, D.E., Fabel, D., Palmer, A.N., 2001. Pliocene-Pleistocene incision of the Green River, 1126 Kentucky, determined from radioactive decay of cosmogenic ${ }^{26} \mathrm{Al}$ and ${ }^{10} \mathrm{Be}$ in Mammoth Cave 1127 sediments: Geological Society of America Bulletin, 113, 825-836.

1128 Granger, D.E. and Muzikar, P.F., 2001. Dating sediment burial with in situ-produced cosmogenic nuclides: theory, techniques, and limitations. Earth Planet. Sci. Lett. 188, 269-281. Guifang, Y., Xujiao Zh., Mingzhong T., Yamin P., Anze C., Zhiliang G., Zhiyun N., Zhen Y., 2011. Geomorphological and sedimentological comparison of fluvial terraces and karst caves in Zhangjiajie, northwest Hunan, China: an archive of sandstone landform development. Environ Earth Sci, 64, 671-683.

1134 Habib, B., 2015. Relations entre karstification, cadre morphostructural et incisions des vallées dans les calcaires du Dogger en Haute-Saône (plateaux de Vesoul et de Combeaufontaine). Thèse de doctorat, Université de Lorraine, $460 \mathrm{p}$.

1137 Harmand, D., Lejeune, O., Jaillet, S., Allouc, J., Occhietti, S., Brulhet, J., Devos, A., Fauvel, 1138 P.-J., Hamelin, B., Laurain, M., Le Roux, J., Marre, A., Pons-Branchu, E., Quinif, Y., 2004.

1139 Dynamique de l'érosion dans le Barrois et le Perthois: incision et karstification dans les bassins1140 versants de la Marne, la Saulx et l'Ornain. Quaternaire, 15, 4, 305-318.

1141 Harmand, D. and Cordier, S., 2012. The Pleistocene terrace staircases of the present and past 1142 rivers downstream from the Vosges Massif (Meuse and Moselle catchments). Netherlands 1143 Journal of geosciences-Geologie en Mijnbouw, 91-1/2, 91-109.

1144 Harvey, A.M., Whitfield, E., Stokes, M. \& Mather, A.E. 2014. The late Neogene to Quaternary 1145 drainage evolution of the uplifted Neogene Sedimentary Basins of Almeria, Betic Chain. 1146 Landscapes and Landforms of Spain, 37-61. 
1147 Häuselmann, P., 2002. Cave genesis and its relationship to surface processes: Investigations in 1148 the Siebenhengste region (BE, Switzerland). - PhD thesis, Université de Fribourg, 168 p.

1149 Häuselmann, P. and Granger, D.E., 2005. Dating of caves by cosmogenic nuclides: method, 1150 possibilities, and the Siebenhengste example (Switzerland). Acta Carsologica, 34/1, 3, 43-50.

1151 Häuselmann, P., Granger, D.E., Jeannin P.Y., Lauritzen S.E., 2007. Abrupt glacial valley

1152 incision at 0.8 Ma dated from caves deposits in Switzerland, Geology, 35, 2, 143-146.

1153 Häuselmann, P., Mihevc, A., Pruner, P., Horáček, I., Čermák, S., Hercman, H., Sahy, D., Fiebig, 1154 M., Hajna, N.Z., Bosák, P., 2015. Snežna jama (Slovenia): Interdisciplinary dating of cave 1155 sediments and implication for landscape evolution. Geomorphology, 247, 10-24.

1156 Hez, G., Jaillet, S., Calvet, M., Delannoy, J.-J, 2015. Un enregistreur exceptionnel de l'incision 1157 de la vallée de la Têt : Le karst de Villefranche. Pyrénées-Orientales - France. Kartologia ${ }^{\circ}$ 1158 65, in press.

1159 Hill, C.A., 1987. Geology of Carlsbad Cavern and other caves in the Guadalupe Mountains, 1160 New Mexico and Texas. New Mexico Bureau of Mines and Mineral Resources. Bulletin 117, $1161150 \mathrm{p}$.

1162 Hobléa, F., Jaillet, S., Maire, R., 2001. Erosion et ruissellement sur karst nu en contexte 1163 subpolaire océanique : les îles calcaires de Patagonie (Magallanes, Chili). Karstologia, 38, 2, $1164 \quad 13-18$.

1165 Hobléa, F., Häuselmann, P., Kubik, P., 2011. Cosmogenic nuclide dating of cave deposits of 1166 Mount Granier (Hauts de Chartreuse Nature Reserve, France): morphogenic and 1167 palaeogeographical implications. Géomorphologie: relief, processus, environnement 4, 3951168406.

1169 Hoke, G. D., Liu-Zeng, J., Hren, M. T., Wissink, G. K., and Garzione, C. N., 2014. Stable 1170 isotopes reveal high southeast Tibetan Plateau margin since the Paleogene. Earth and Planetary 1171 Science Letters, 394, 270-278.

1172 Hughes, P. D., Woodward, J. C. and Gibbard, P. L. (2006). Quaternary glacial history of the 1173 Mediterranean mountains. Progress in Physical Geography, 30(3), 334-364.

1174 Hughes, P. D., Woodward, J. C., van Calsteren, P. C., Thomas, L. E., Adamson, K. R., 2010, 1175 Pleistocene ice caps on the coastal mountains of the Adriatic Sea. Quaternary Science Reviews, 117629 (27-28), 3690-3708.

1177 Hughes, P.D., Woodward, J.C., Van Calsteren, P.C. and Thomas, L.E., 2011. The glacial 1178 history of the Dinaric Alps, Montenegro. Quaternary Science Reviews, 30(23), 3393-3412.

1179 Huxtable, J., Aitken, M. J., 1991. Thermoluminescence dating: results for the late Pleistocene. 1180 In: Raynal, J.-P., Miallier, D. (éd.). Datation et caractérisation des milieux pléistocènes. Cah. 
1181 Quat., CNRS, Paris (actes des symposiums 11 et 17 de la 11 ème réunion des Sciences de la

1182 Terre, Clermont-Ferrand, 25-27 mars 1986), 16, 19-24.

1183 Jaillet, S., 2000. Un karst couvert de bas-plateau : le Barrois (Lorraine / Champagne, France).

1184 Structure - Fonctionnement - Evolution. Thèse de doctorat, Université de Bordeaux III, 2 vol., $1185712 \mathrm{p}$

1186 Jaillet, S., Pons-branchu, E., Brulhet, J., Hamelin, B., 2004. Karstification as a 1187 geomorphological witness of river incision: example of the Marne Valley and Cousance karst 1188 system (Eastern Paris Bassin). Terra Nova, 16, 4, 167-172.

1189 Kukla, G., 2005. Saalian supercycle, Mindel/Riss Interglacial and Milankovitch's dating. 1190 Quaternary Science Reviews, 24, 14-15, 1573-1583.

1191 Le Roux, J. and Harmand, D., 1998. Contrôle morphostructural de l'histoire d'un réseau 1192 hydrographique : le site de la capture de la Moselle. Geodinamica acta, 11, 4, 149-162.

1193 Le Roux, J. and Harmand, D., 2003. Origin of the hydrographic network in the Eastern Paris 1194 Basin and its border massifs. Hypothesis, Structural, Morphologic and Hydrologic 1195 consequences. Special conference on paleoweathering and paleosurfaces in the Ardenne-Eifel region at Preizerdaul (Luxembourg) on 14 to 17 may 2003, Quesnel, coordinator, Géologie de la France, 1, 4, 105-110.

1198 Lewin, J. and Gibbard, P.L., 2010. Quaternary river terraces in England: Forms, sediments and 1199 processes. Geomorphology 120, 293-311.

1200 Lewin, J. and Woodward, J., 2009. Karst Geomorphology and Environnemental Change 1201 (chapter 10). In: Woodward, J. Ed., 2009. The Physical Geography of the Mediterranean. 1202 Oxford University Press, 287-317.

1203 Limondin-Lozouet, N., Antoine, P., Auguste, P., Bahain, J.-J., Carbonel, P., Chaussé, Ch., 1204 Connet, N., Dupéron, J., Dupéron, M., Falguères, Ch., Freytet, P., Ghaleb, B., Jolly-Saad, M.1205 C., Lhomme, V., Pierre Lozouet, P., Mercier, N., Pastre, J.-F., Voinchet, P., 2006. Le tuf 1206 calcaire de La Celle-sur-Seine (Seine et Marne) : nouvelles données sur un site clé du stade 11 1207 dans le Nord de la France. Quaternaire, 17, 2, 5-29.

1208 Liu, Y., Wang, S.J., Xu, S., Liu, X.M., Fabel, D., Zhang, X.B., Luo, W.J., Cheng, A.Y., 2013. 1209 New evidence for the incision history of the Liuchong River, Southwest China, from cosmogenic ${ }^{26} \mathrm{Al} /{ }^{10} \mathrm{Be}$ burial ages in cave sediments. J. Asian Earth Sci., 73, 274-283.

1211 Losson, B., 2003. Karstification et capture de la Moselle (Lorraine, France) : vers une 1212 identification des interactions. Thèse de Géographie physique. Université de Metz. Vol. 1 1213 (texte) : 510 p, Vol. des planches : 89 pl., Vol. des annexes, 227 p. 
1214 Losson, B., Corbonnois, J., Argant, J., Brulhet, J., Pons-Branchu, E., Quinif, Y., 2006.

1215 Interprétation paléoclimatique des remplissages endokarstiques de la vallée de la Moselle à

1216 Pierre-la-Treiche (Lorraine, France). Géomorphologie : relief, processus, environnement, 1, $1217 \quad 37-48$.

1218 Lucha, P., Gutiérrez, F., Pedro Galve, J., Guerrero, J., 2012. Geomorphic and stratigraphic 1219 evidence of incision-induced halokinetic uplift and dissolution subsidence in transverse 1220 drainages crossing the evaporite-cored Barbastro-Balaguer Anticline (Ebro Basin, NE Spain). 1221 Geomorphology, 171-172, 154-172.

1222 Mangin, A., 1975. Contribution à l'étude hydrodynamique des aquifères karstiques. Annales de spéléologie, $29, \mathrm{n}^{\circ} 3,283-332 ; 29, \mathrm{n}^{\circ} 4,495-601 ; 30, \mathrm{n}^{\circ} 1,21-124$. Thèse d'état, Dijon.

1224 Mather, A.E., 2000. Adjustment of a drainage network to capture induced base-level change: an example from the Sorbas Basin, SE Spain. Geomorphology, 34, 3-4, 271-289.

1226 McPhillips, D., Hoke, G. D., Liu-Zeng, J., Bierman, P. R., Rood, D. H., Niedermann, S., 2016.

1227 Dating the incision of the Yangtze River gorge at the First Bend using three-nuclide burial ages, 1228 Geophys. Res. Lett., 43, 101-110.

1229 Mocochain, L., Clauzon, G., Bigot, J.-Y., 2006. Réponses de l'endokarst ardéchois aux variations eustatiques générées par la crise de salinité messinienne. Bulletin de la Société géologique de France, Paris, 177, 1, 27-36. Mocochain, L., Audra, P., Clauzon, G., Bellier., O., Bigot, J.-Y., Monteil, Ph., 2009. The effect of river dynamics induced by the Messinian Salinity Crisis on karst landscape and caves: example of the Lower Ardèche River (and Rhône valley). Geomorphology, 106, 46-61. Moreno, D., Falguères, Ch., Pérez-González, A., Duval, M., Voinchet, P., Benito-Calvo, A., Ortega, A. I., Bahain, J.-J., Sala, R., Carbonell, E., Bermúdez de Castro, J. M., Arsuaga, J.L., 2012. ESR chronology of alluvial deposits in the Arlanzón valley (Atapuerca, Spain): Contemporaneity with Atapuerca Gran Dolina site. Quaternary Geochronology, 10, 418-423. Nicod, J., 2010. Les étapes de la karstologie en France. In: Audra, P., Ed, 2010. Grottes et karsts de France. Karstologia Mémoires, 19, 16-17.

1241 Ortega, A.I., Benito-Calvo, A., Pérez-González, A., Martín-Merino, M.A., Pérez-Martínez, R., 1242 Parés, J.M., Aramburu, A., Arsuaga, J.L., Bermúdez de Castro, J.M., Carbonell, E., 2013. 1243 Evolution of multilevel caves in the Sierra de Atapuerca (Burgos, Spain) and its relations to 1244 human occupation. Geomorphology, 196, 122-137.

1245 Osborne, R. A. L., 2007. The world's oldest caves: how did they survive and what can they tell 1246 us? Acta carsologica, 36, 133-142. 
1247 Palmer, A.N., 1991. Origin and morphology of limestone caves. Geological Society of America 1248 Bulletin 103, 1-21.

1249 Palmer, A.N, 2007. Cave geology. Cave books, 454 p.

1250 Palmer, A.N. and Palmer, M.V., 1993, Geologic leveling survey in Logsdon River, Mammoth 1251 Cave: Cave Research Foundation Annual Report 1992, 32-34.

1252 Piccini, L., 2011. Speleogenesis in highly geodynamic contexts: The quaternary evolution of 1253 Monte Corchia multi-level karst system (Alpi Apuane, Italy). Geomorphology, 134, 49-61.

1254 Pons-Branchu E., Hamelin B., Losson B., Jaillet S., Brulhet J., 2010. Speleothem evidence of 1255 warm episodes in northeast France during Marine Oxygen Isotope Stage 3 and implications for 1256 permafrost distribution in northern Europe. Quaternary Research, 2010, 74 (2), p. 246-251.

1257 Quinif, Y., 1989. La notion d'étages de grottes dans le karst belge. Karstologia, 13, 41-49.

1258 Quinif, Y., 1999. Karst et évolution des rivières : le cas de l'Ardenne. Geodinamica Acta, 1259 Elsevier, Paris, 12, 3-4, 267-277.

1260 Quinif, Y., 2006. Complex stratigraphic sequences in Belgian caves: correlation with climatic 1261 changes during the middle, the upper Pleistocene, and the Holocene. Geologica Belgica [En 1262 ligne], number 3-4 - Han-sur-Lesse Symposium - nov. 2004, 9, 231-244.

1263 Quinif, Y., 2010. Fantômes de roche et fantômisation. Essai sur un nouveau paradigme en 1264 karstogenèse. Karstologia Mémoires, 18, $196 \mathrm{p}$.

1265 Quinif, Y. and Maire, R., 1998. Pleistocene deposits in Pierre-Saint-Martin cave, French 1266 Pyrenees. Quaternary Research, 49, 37-50.

1267 Richard, M., C. Falguères, Pons-Branchu, E., Bahain, J.-J., Voinchet, P., Lebon, M., Valladas, 1268 H., Dolo, J.-M., Puaud, S., Rué, M., Daujeard, C., Moncel, M.-H., Raynal, J.-P., 2015. 1269 Contribution of ESR/U-series dating to the chronology of late Middle Palaeolithic sites in the 1270 middle Rhône valley, Southeastern France. Quaternary Geochronology 30, 529-534.

1271 Rixhon, G. \& Demoulin, A. 2010. Fluvial terraces of the Amblève: a marker of the Quaternary 1272 river incision in the NE Ardenne massif (western Europe). Zeitschrift für Geomorphologie 54, $1273 \quad 161-180$.

1274 Rixhon, G., Braucher, R., Bourlès, D., Siame, L., Bovy, B., Demoulin, A., 2011. Quaternary 1275 river incision in NE Ardennes (Belgium) - insights from ${ }^{10} \mathrm{Be} /{ }^{26} \mathrm{Al}$ dating of river terraces. 1276 Quat. Geochronol. 6, 273-284.

1277 Rixhon, G., Bourlès, D.L., Braucher, R., Siame, L., Cordy, J.-M., \& Demoulin, A., 2014. ${ }^{10}$ Be 1278 dating of the Main Terrace level in the Amblève valley (Ardennes, Belgium): new age 1279 constraint on the archaeological and palaeontological filling of the Belle-Roche palaeokarst. 1280 Boreas, 43, 2, 528-542. 
1281 Rixhon, G., Briant, R.M., Cordier, S., Duval, M., Jones, A., Scholz, D., 2016 (in press).

1282 Revealing the pace of river landscape evolution during the Quaternary: recent developments in

1283

1284

1285

1286

1287

1288

1289

1290

1291

1292

1293

1294

1295

1296

1297

1298

1299

1300

1301

1302

1303

1304

1305

1306

1307

1308

1309

1310

1311

1312

1313 numerical dating methods. Quaternary Science Reviews.

Rodet, J., 1992. La craie et ses karsts. Centre normand d'étude du karst et des cavités du soussol et Groupe Seine, Rouen, 560 p.

Rodet, J., 2013. Karst et évolution géomorphologique de la côte crayeuse à falaises de la Manche. L'exemple du Massif d'Aval (Etretat, Normandie, France). Quaternaire, Paris, 24, 3, 303-314.

Rohling, E. J., Grant, K., Bolshaw, M., Roberts, A. P., Siddall, M., Hemleben, Ch., Kucera, M., 2009. Antarctic temperature and global sea level closely coupled over the past five glacial cycles. Nature Geoscience 2, $500-504$.

Seranne, M., Camus, H., Lucazeau, F., Barbarand, J., Quinif, Y., 2002. Surrection et érosion polyphasées de la Bordure cévenole. Un exemple de morphogenèse lente. Bulletin Société Géologique de France, 173, 2, 97-112.

Stepišnik, U., Ferk, M., Kodelja, B., Medenjak, G., Mihevc, A., Natek, K., Žebre, M., 2009. Glaciokarst of western Orjen, Montenegro. Cave and Karst Science 36 (1), 21-28.

Stock, G.M., Anderson, R.S., Finkel, R.C., 2004. Pace of landscape evolution in the Sierra Nevada, California, revealed by cosmogenic dating of cave sediments. Geology, 32, 193-196.

Stock, G.M., Anderson, R.S., Finkel, R.C., 2005. Rates of erosion and topographic evolution of the Sierra Nevada, California, inferred from cosmogenic 26Al and 10Be concentrations. Earth Surf. Process. Landforms, 30, 985-1006.

Stokes, M., Mather, A. E., Harvey, A. M., 2002. Quantification of river-capture-induced baselevel changes and landscape development, Sorbas Basin, SE Spain. Geological Society, London, Special Publications 191, 23-35.

Tassy, A., Mocochain, L., Bellier, O., Braucher, R., Gattacceca, J., Bourlès, D., 2013. Coupling cosmogenic dating and magnetostratigraphy to constrain the chronological evolution of periMediterranean karsts during the Messinian and the Pliocene: Example of Ardèche Valley, Southern France. Geomorphology, 189, 81-92.

Tassy, A., Fournier, F., Munch, P., Borgomano, J., Thinon, I., Fabri, M.-C., Rabineau, M., Arfib, B., Begot, J., Beslier, M.-O., Cornée, J.-J., Fournillon, A., Gorini, C., Guennoc, P., Léonide, P., Oudet, J., Paquet, F., Sage, F., Toullec, R., 2014. Discovery of Messinian canyons and new seismic stratigraphic model, offshore Provence (SE France): Implications for the hydrographic network reconstruction. Marine and Petroleum Geology, 57, 25-50. 
1314 Tognini, P., 1999. The Mt. Bisbino (Northern Italy) karst: a new speleogenetic process. Etudes

1315 de géographie physique, supplément $n^{\circ}$ XXVIII [proceedings of the European Conference " 1316 Karst 99 ", Grands Causses - Vercors, 10-15 September 1999], CAGEP, Université de 1317 Provence, 185-190.

1318 Vergari, A. and Quinif, Y., 1997. Les paléokarsts du Hainaut (Belgique). Geodinamica Acta, $131910,4,175-187$.

1320 Vernet, J.-L., Mercier, N., Bazile F., Brugal, J.-P., 2008. Travertins et terrasses de la moyenne 1321 vallée du Tarn à Millau (sud du Massif central, Aveyron, France) : datations OSL, contribution 1322 à la chronologie et aux paléoenvironnements. Quaternaire, 19, 1, 3-10.

1323 Wagner, T., Fabel, D., Fiebig, M., Häuselmann, P., Sahy, P., Sheng Xu, Kurt Stüwe, 2010.

1324 Young uplift in the non-glaciated parts of the Eastern Alps. Earth and Planetary Science Letters $1325295,159-169$.

1326 Waltham, A.C., Simms, M.J., Farrant, A.R. \& Goldie, H.S., 1997, Karst and Caves of Great 1327 Britain, Geological Conservation Review. Series, No. 12, Chapman and Hall, London, 358 p. 1328 Wang, F., Li, H., Zhu, R., Qin, F., 2004. Late Quaternary downcutting rates of the Qianyou River from U/Th speleothem dates, Qinling mountains, China. Quat. Research, 62, 194- 200. Webb, J.A., Fabel, D., Finlayson, B. L., Ellaway, M., Shu,L., Spiertz, H.-P., 1992. Denudation chronology from cave and river terrace levels: the case of the Buchan Karst, southeastern Australia. Geol. Mag. 129, 3, 307-317.

White, W. B., 1988. Geomorphology and hydrology of karst terrains. Oxford University press, $1334464 \mathrm{p}$.

1335 Whittaker, A. C., Boulton, S. J. (2012). Tectonic and climatic controls on knickpoint retreat rates and landscape response times, J. Geophys. Res., 117, F02024.

Woodward, J.C., Hamlin, R. H. B., Macklin, M. G., Hughes, P. D., and Lewin, J., 2008. Glacial activity and catchment dynamics in northwest Greece: Long-term river behaviour and the slackwater sediment record for the last glacial to interglacial transition. Geomorphology, 101,12: 44-67.

1344 Figure 1: Location map of the karstic areas discussed in the text.

1345 Figure 2: Schematic diagrams of the relationships between valley evolution and karstification:

1346 A) The concept of correlation between surface features (alluvial terraces) and subsurface 1347 karstification levels (caves) (modified from Abel et al., 2002); B) Different types of cave profile 
1348 development, constrained by recharge ( $\mathrm{a}$ and $\mathrm{b}$ ) and base-level controls (c and d) (after Audra 1349 \& Palmer, 2011).

1350 Figure 3: Typology of the relationships between karst and valley incision, demonstrating the 1351 type of speleogenesis, characteristic morphologies, and examples (after Losson, unpublished)

1352 Figure 4: Karst and entrenched valleys in the Eastern Paris Basin: A) Typology of the relations 1353 between karstification and valley evolution; B) hydraulic gradient between aquifer 1354 compartments and rivers (after Devos, unpublished).

1355 Figure 5: Idealised models of per descensum (A) and per ascensum (B) speleogenesis using 1356 examples from the Vercors Subalpine Chain (A) and the Lower Ardèche River (B).

1357 Figure 6: Two conceptual models of gypsum karst: A: interstratal karstification with contemporary underground erosion processes (after Calaforra \& Pulido-Bosch, 2003); B: karst subsidence and accelerated fluvial aggradation (after Benito et al., 2010)

1360 Figure 7: A conceptual model of valley scale karstic and fluvial development in relation to river 1361 terrace records: A) successive stages of evolution of a karstic drain and a valley floor, B) 1362 schematic cross-section of relationships between cave passage and valley terrace during phase 4 (upstream part); C) Model elevation / time of the hydrographic network and the cave passage (Jaillet, unpublished)

1365 Figure 8: Valley entrenchment during a Pleistocene glacial-interglacial cycle in limestone areas. A: connected cave and base levels of a same valley (plateau karst); B) speleogenesis in connection with an neighbouring valley (valley karst) (after Antoine, 1994; Losson, 2003; Antoine et al., 2006; Quinif, 2006)

1369 Figure 9: Conceptual model of climate-driven speleogenesis of gypsum cave systems in relation with valley incision and aggradation in moderately and rapid uptlifted gypsum area: A) climatedriven speleogenesis of epigenic gypsum cave systems, B) evolution of river valleys and adjacent gypsum cave systems (based on the Northern Apennines after Colombu et al., 2015) 


\section{$1381 \quad$ Figure 1}

1382

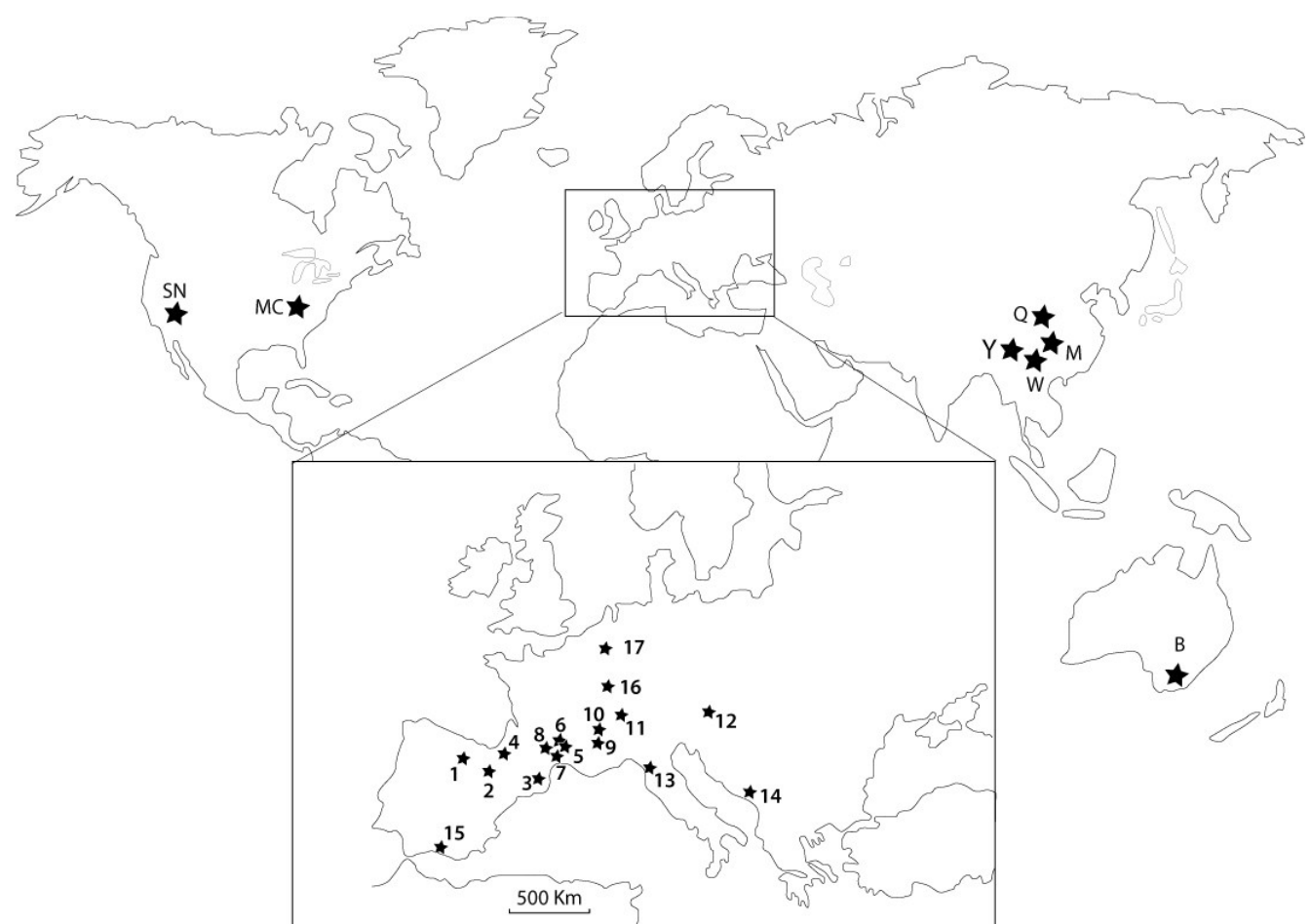

B: caves of Buchan, Australia; MC: Mammoth cave, USA; SN : Sierra Nevada, USA; M: Miaoxi River, Hunan, China; Q: Qianyou River, Qinling mountains, China; W: Wujiang River, Guizhou, China;Y:Yangzi Gorge,Yunnan, China; Europe: 1: Arlanzón, Spain; 2: Gállego River, Spain; 3: Têt valley, Eastern Pyrenees, France; 4: Pierre-Saint-Martin, Western Pyrenees, France; 5: Lower Ardèche valley, France; 6: Middle Ardèche valley, France; 7 : Southern Larzac plateau, Grands Causses, France; 8: Tarn valley at Millau, Grands Causses, France; 9: Vercors, subalpine massif, France; 10: Mont Southern Larzac plateau, Grands Causses, France; 8: Tarn valley at Millau, Grands Causses, France; 9: Vercors, subalpine massif, France; 10: Mont
Granier, Grande Chartreuse, subalpine massif, France; 11: Siebenhengste, Switzerland; 12: Mur valley, Eastern Alps, Austria; 13: Monte Corcia, Granier, Grande Chartreuse, subalpine massif, France; 11: Siebenhengste, Switzerland; 12: Mur valley, Eastern Alps, Austria; 13: Monte Corcia, 

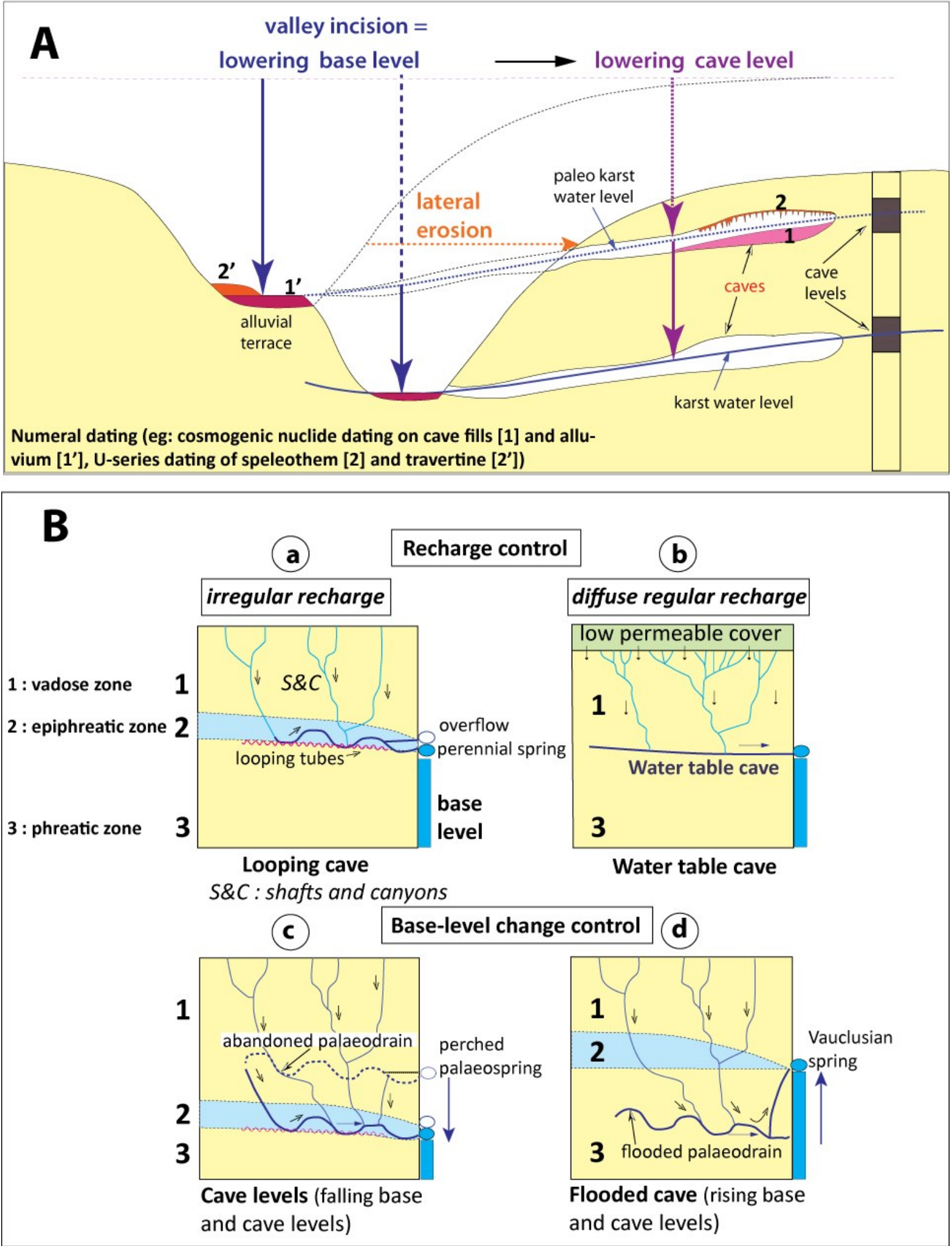


\section{Figure 3}

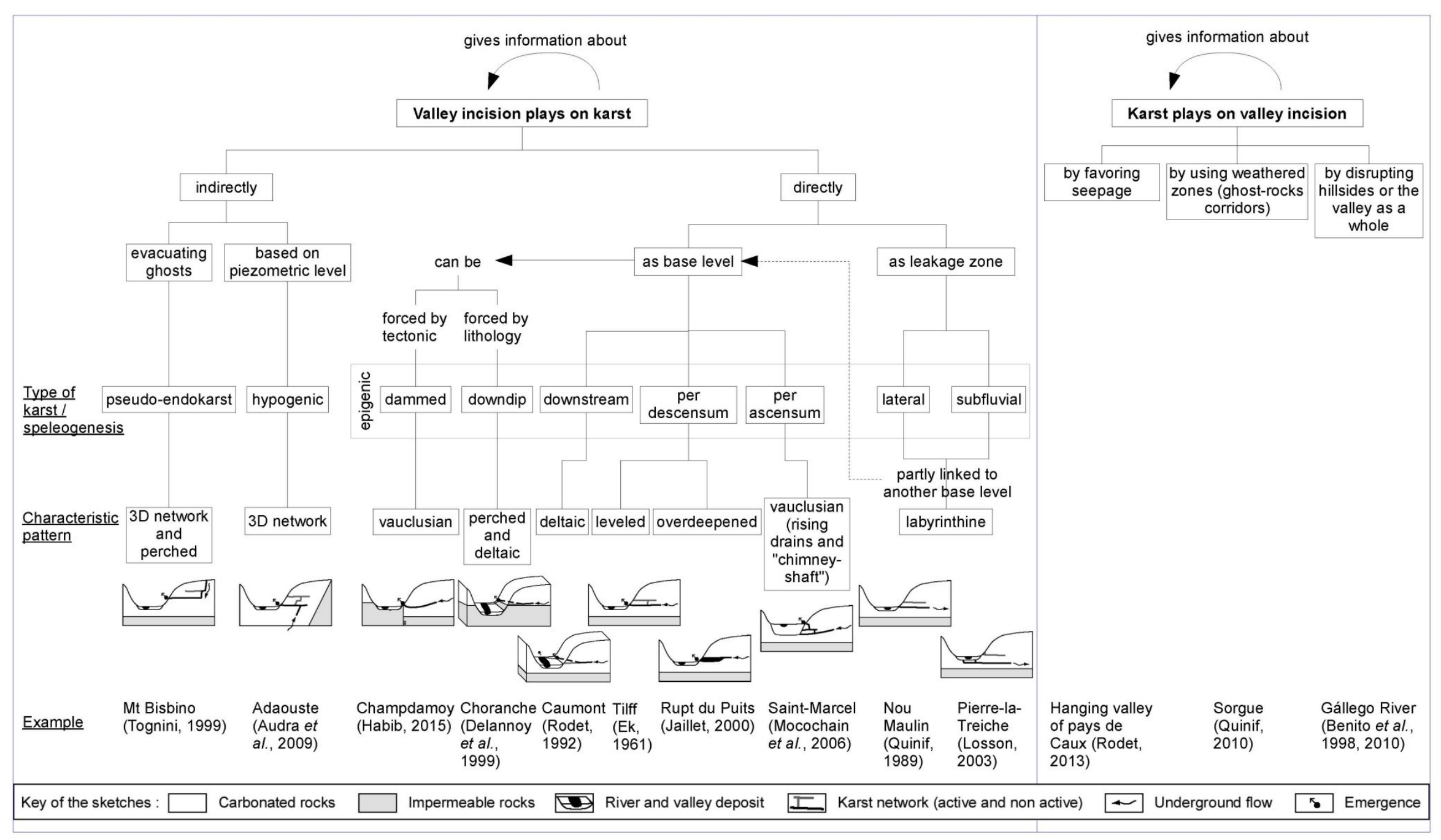


Figure 4
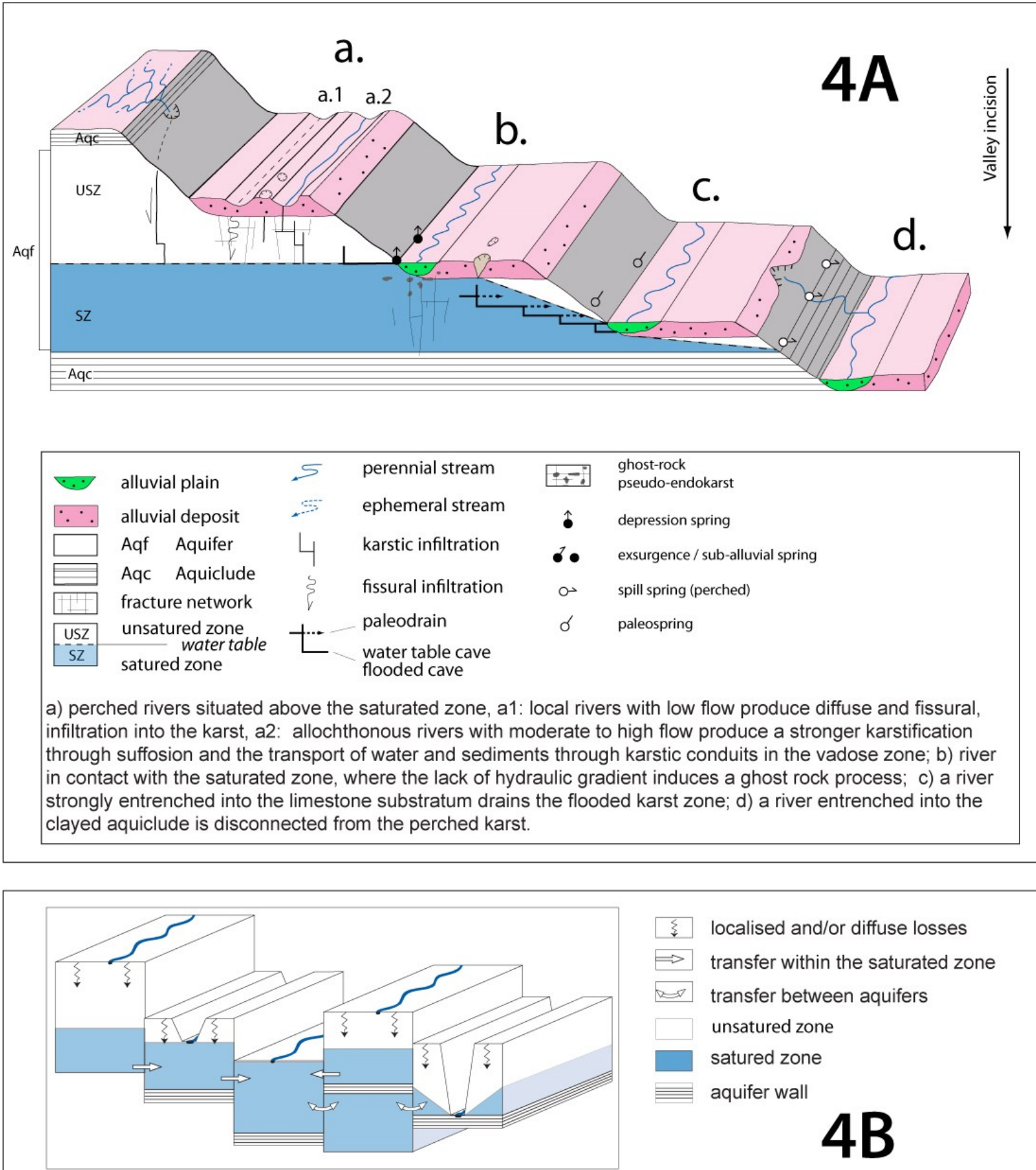

localised and/or diffuse losses

transfer within the saturated zone

transfer between aquifers

unsatured zone

satured zone

aquifer wall

4B 


\section{Figure 5}
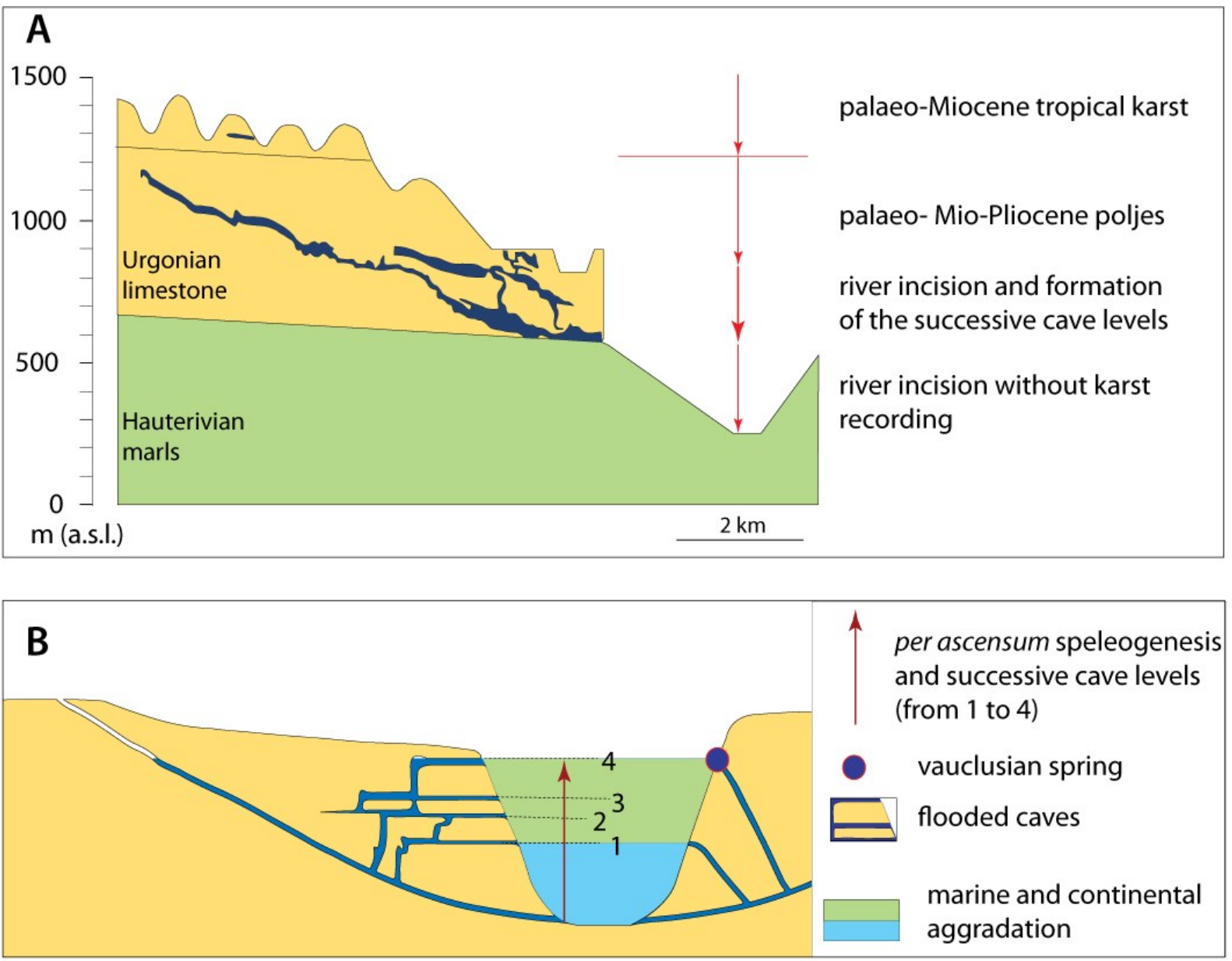

A: Per descensum speleogenesis incision in connection with uplift and valley incision (model of the Vercors subalpin chain, after Delannoy et al., 2009); B: Per ascensum speleogenesis : model of the Lower Ardèche river (after Audra \& Palmer, 2011) 


\section{Figure 6}
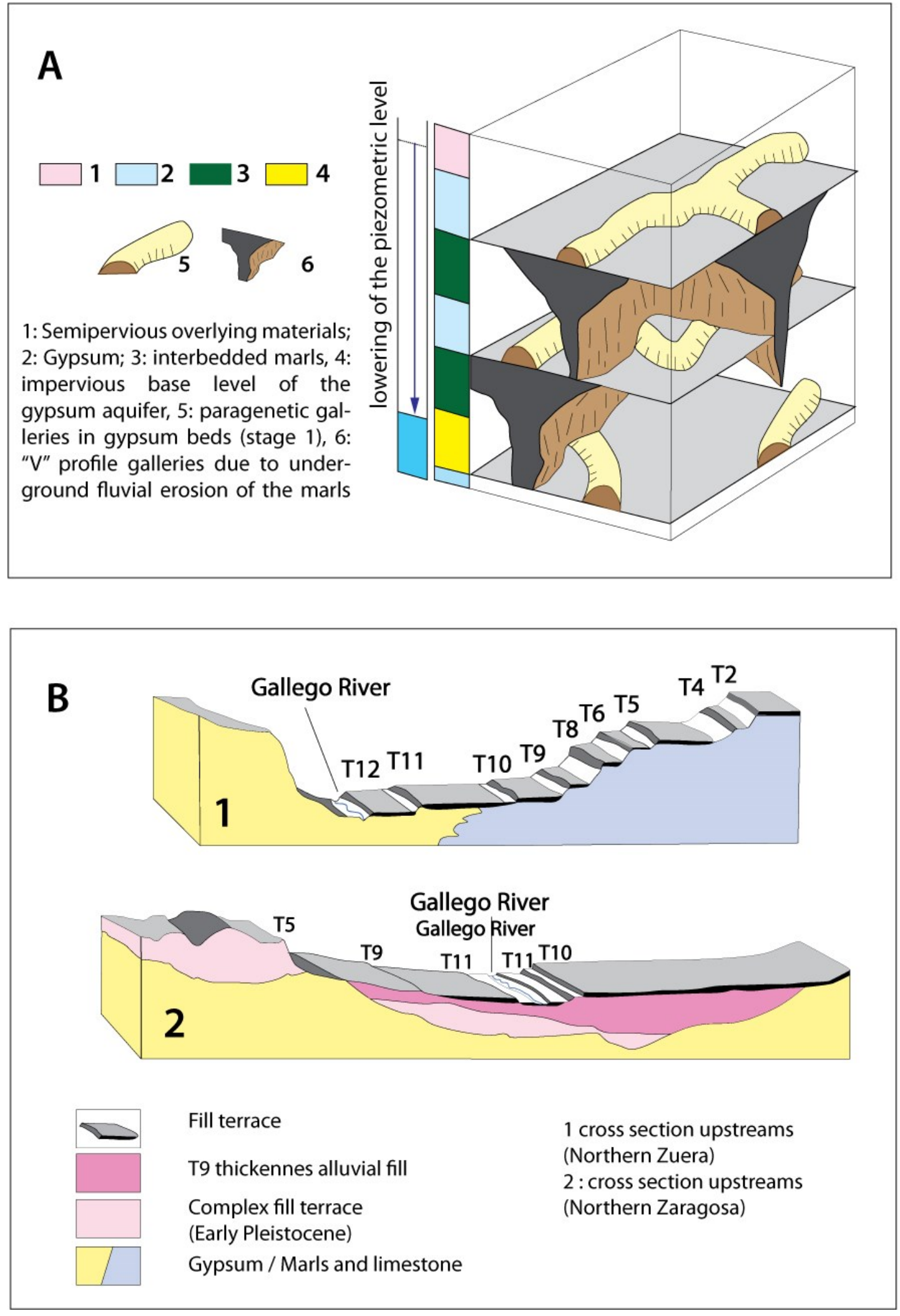


\section{Figure 7}

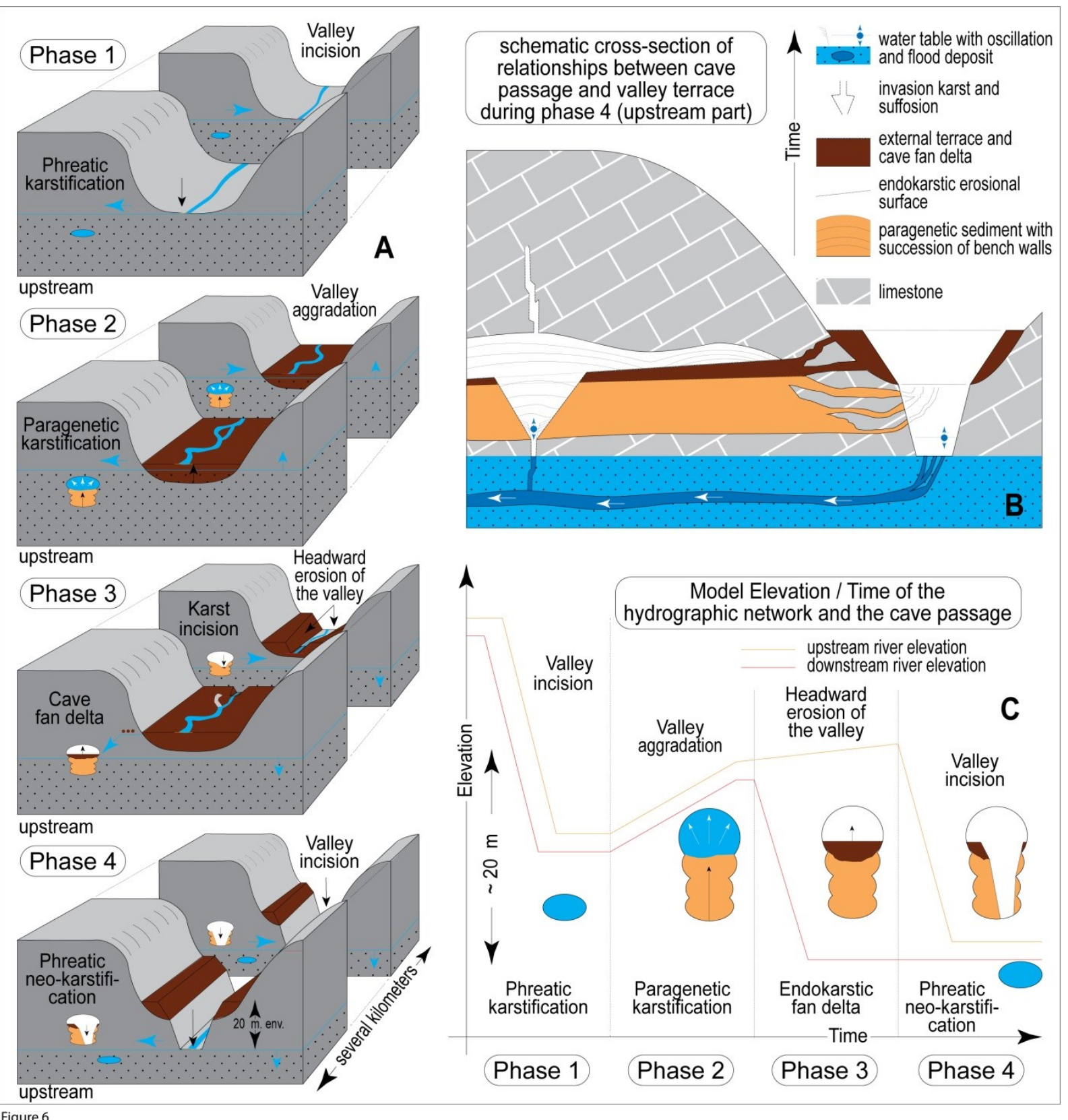

Figure 6 
Figure 8:

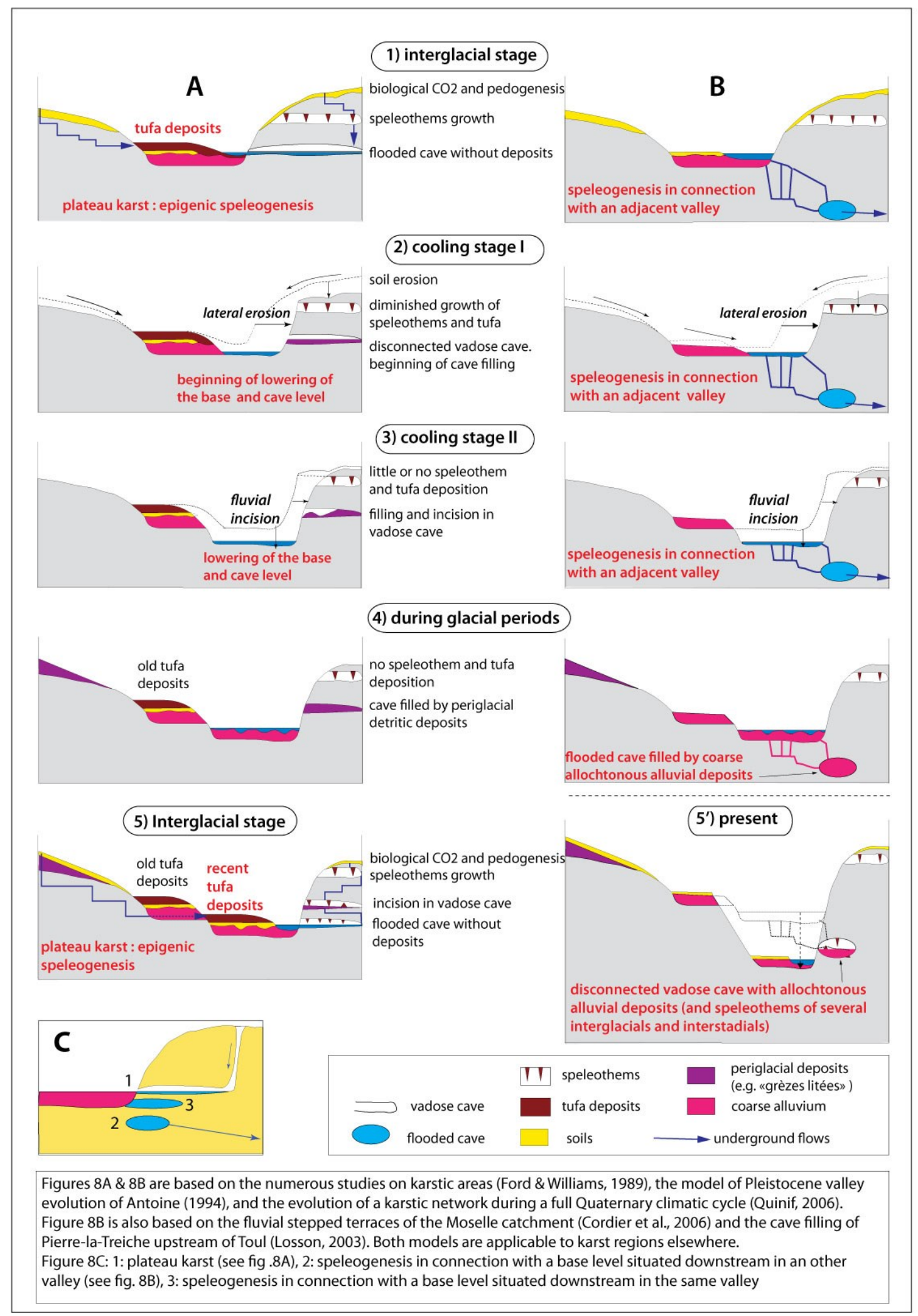


Figure 9:

A

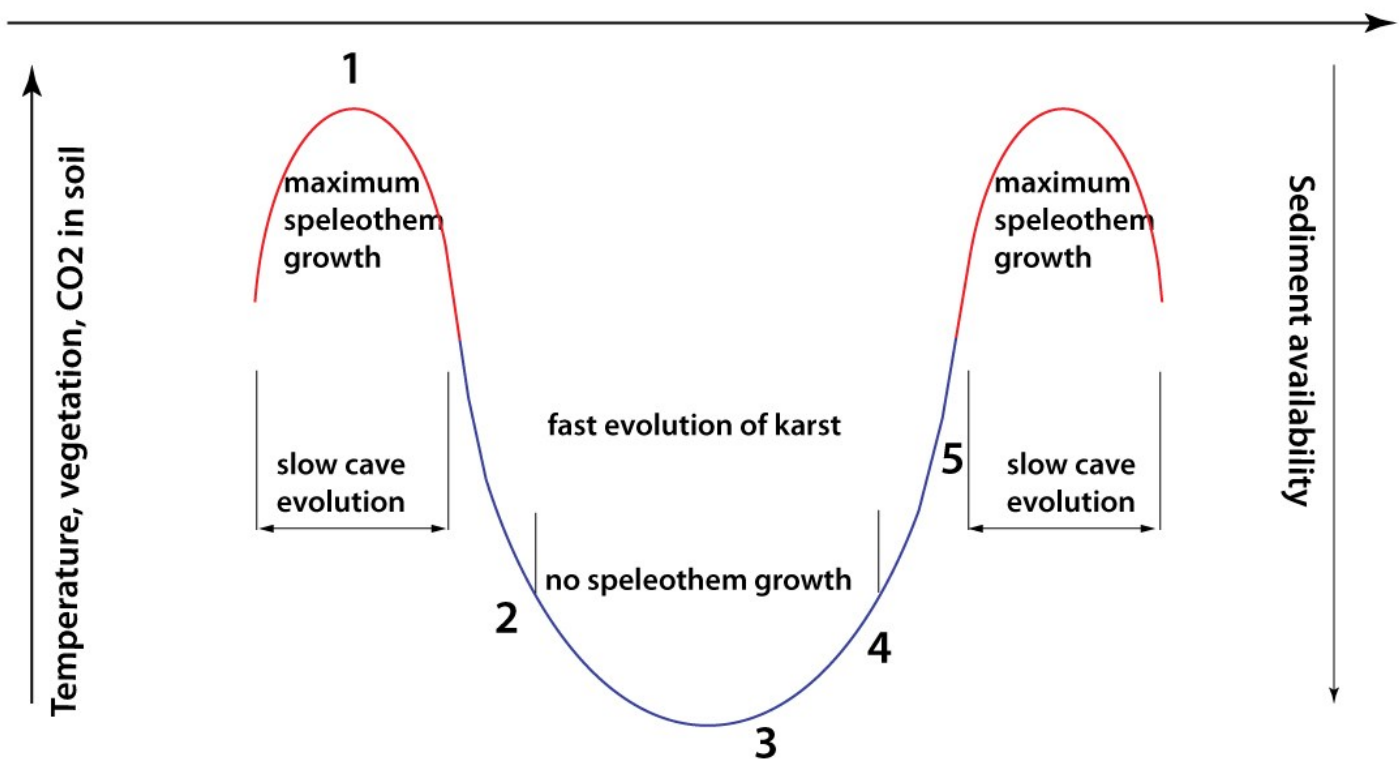

B
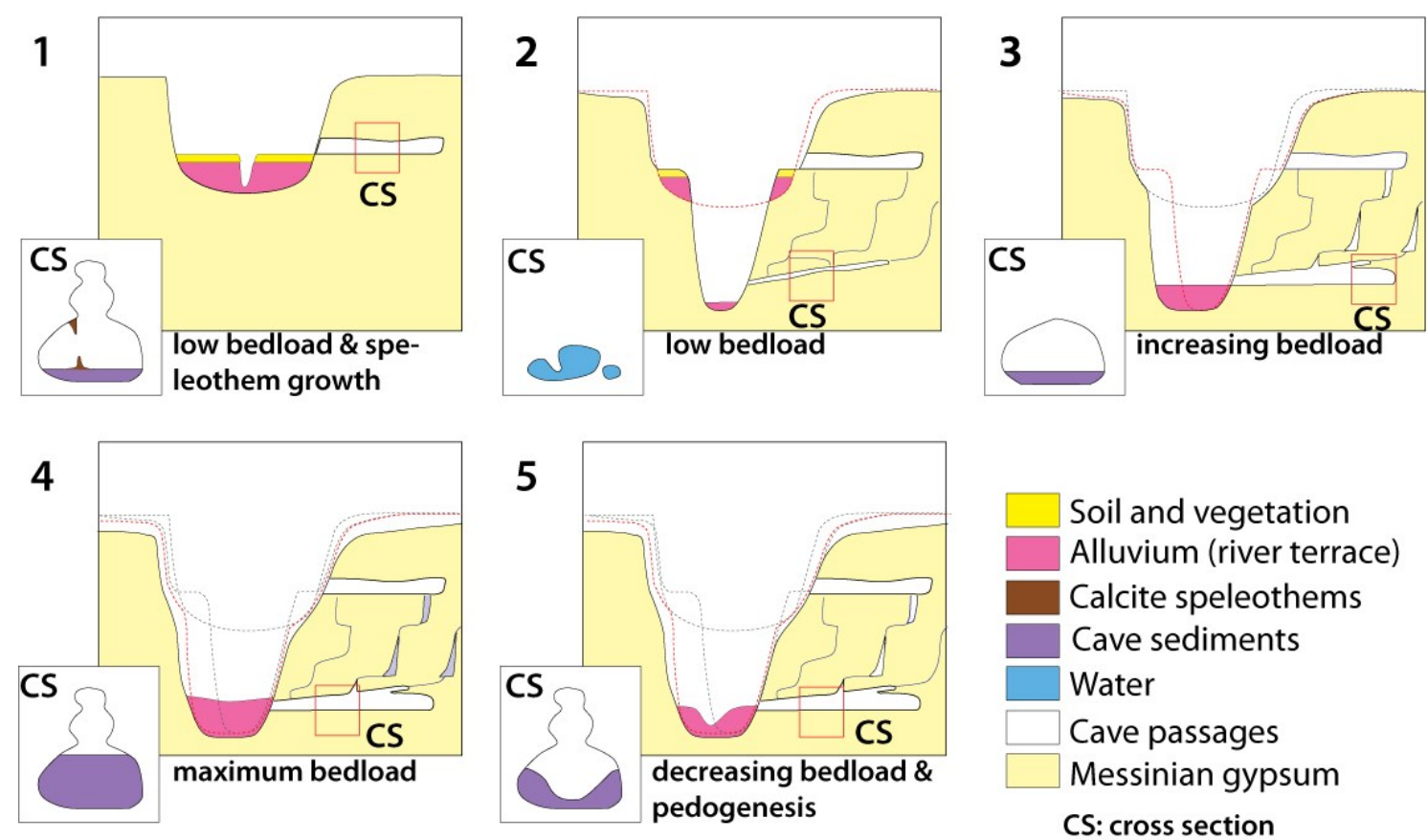

Soil and vegetation Alluvium (river terrace)

Calcite speleothems

Cave sediments

Water

Cave passages

Messinian gypsum

CS: cross section of the caves 